PONTIFÍCIA UNIVERSIDADE CATÓLICA DO RIO DE JANEIRO

Avaliação de entendimento sobre planejamento financeiro de pessoas economicamente ativas.

Luciene Queiroz

Trabalho de Conclusão de Curso

Centro de ClÊnCIAS SOCIAIS - CCS

DePARTAMENTO de AdMINISTRAÇÃo

Graduação em Administração de Empresas 
Luciene Queiroz

\section{Avaliação de entendimento sobre planejamento financeiro de pessoas economicamente ativas}

Trabalho de Conclusão de Curso, apresentado ao programa de graduação em Administração da PUC-Rio como requisito parcial para a obtenção do título de graduação em Administração.

Orientador(a) : Liana Ribeiro dos Santos 


\section{Agradecimentos}

Em minha vida, importo-me, sobretudo, com as pessoas que permanecem ao meu lado seja qual for à empreitada. $E$ nesse sentido, não somente durante todo o processo de criação deste trabalho, mas como também em toda a caminhada até aqui, muitos foram aqueles que dedicaram seu tempo para me ajudar e me deram o apoio para que continuasse em frente.

Assim, primeiramente, agradeço a Deus por colocar essas pessoas em minha vida, pois sem elas esse caminho seria muito mais difícil.

Ao meu pai e as minhas duas mães, que me amam e que sempre estiveram e estarão ao meu lado.

Ao meu companheiro de vida, que sempre com muito amor e paciência, me compreendeu e me ajudou.

Aos meus avós que partiram durante essa caminhada, que me protegem onde eles estão.

Aos meus, toda minha gratidão, amor e respeito. 


\section{Resumo}

Queiroz, Luciene. Avaliação de entendimento sobre planejamento financeiro de pessoas economicamente ativas. Rio de Janeiro, 2019. 54 p. Trabalho de conclusão de curso Departamento de Administração. Pontifícia Universidade Católica do Rio de Janeiro.

Saber gerenciar as próprias finanças deveria ser algo básico e indispensável para todos que desejam uma estabilidade financeira. Há muitos fatores que podem colaborar para que isso seja possível: a elaboração de um planejamento e orçamento pessoal; não criar dividas; aprender e conhecer sobre investimentos. O presente trabalho tem por objetivo, avaliar o nível de conhecimento de um grupo de pessoas sobre planejamento financeiro pessoal e identificar se aplicavam o conhecimento em sua rotina. Para isso, foi realizada uma pesquisa através de questionário para levantar essas informações. Foi possível identificar, que apesar do planejamento não ser tão aplicado por essas pessoas, elas compreendem a necessidade de um e como isso pode ser um auxiliador financeiro.

Palavras- chave:

Planejamento financeiro, finanças pessoais, conhecimento financeiro, investimentos, planejamento financeiro pessoal. 


\section{Abstract}

Queiroz, Luciene. Evaluation of understanding about financial planning of economically active people. Rio de Janeiro, 2019. 54 p. Trabalho de Conclusão de Curso - Departamento de Administração. Pontifícia Universidade Católica do Rio de Janeiro.

Knowing how to manage your own finances should be a basic and indispensable thing for everyone who wants financial stability. There are many factors that can help to make this possible; the preparation of personal planning and budget, do not create debts, learn and know about investments. The objective of this study is to evaluate the level of knowledge of a group of people about personal financial planning and to identify if they applied knowledge in their routine. For this, a survey was conducted through a questionnaire to collect this information; so it is possible to identify that although the planning is not so applied by these people, they understand the need for one and how this can be a financial helper.

Key-words:

Financial planning, personal finance, financial knowledge, investments, personal financial planning. 


\section{LISTA DE GRÁFICOS}

Grafico 1 - Indicador de Alfabetismo Funcional - Comportamento ....................................................10

Grafico 2 - Indicador de Alfabetismo Funcional - Conhecimento..................................................... 10

Grafico 3 - Indicador de Alfabetismo Funcional - Atitude .............................................................10

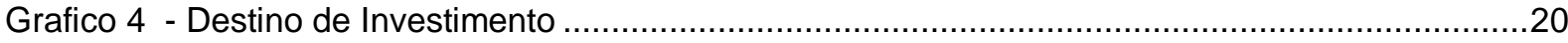

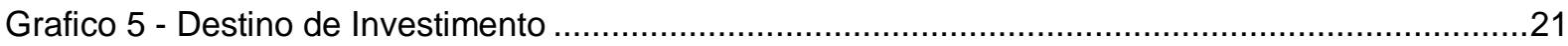

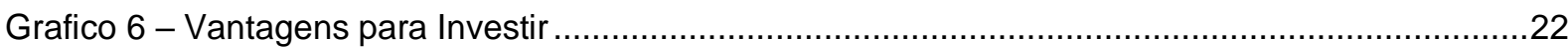

Gráfico 7 - Incluindo todas as suas fontes de renda, você se sente com seus ganhos? ....................29

Gráfico 8 - A sua renda mensal é suficiente para arcar com todas as despesas do mês? ...................30

Gráfico 9 - Você realiza algum orçamento mensal? ......................................................................31

Gráfico 10- Você possuiu algum tipo de reserva? Caso ocorra um imprevisto, qual seria o impacto

dele na sua vida financeira?...

Gráfico 11 - Você sabe como irá realizar seus sonhos e desejos de curto prazo (até um ano) e longo

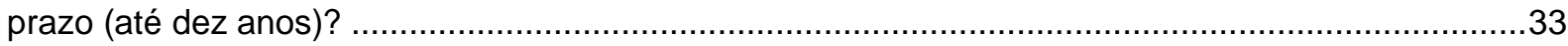

Gráfico 12 - Como você considera a movimentação do seu patrimônio nos últimos cinco anos? ........35

Gráfico 13 - Você acha que seu estilo de vida é condizente com a sua renda atual? .........................36

Gráfico 14 - Qual das seguintes afirmativas melhor descreve sua situação atual de endividamento?

Consideramos endividamento ao conjunto de todos os seus compromissos financeiros. ...................37

Gráfico 15 - Você se considera uma pessoa preparada para fazer uso de cartão de crédito sem

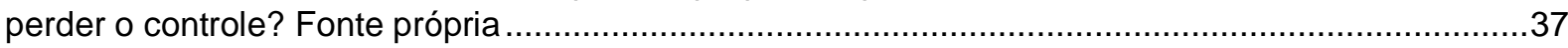

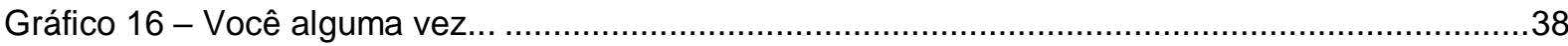

Gráfico 17 - Nos últimos doze meses, qual destas afirmativas descreve sua atitude de

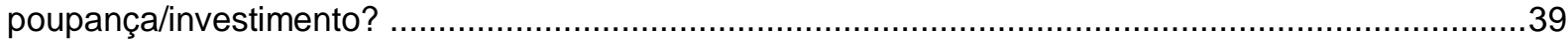

Gráfico 18 - Qual das seguintes afirmativas melhor descreve sua posição atual de investimento? ....40

Gráfico 19 - Na sua opinião, o que mais causa incerteza na hora de realizar um investimento? .........42

Gráfico 20 - Ainda que você não seja um investidor, que frase define melhor sua opinião quanto ao

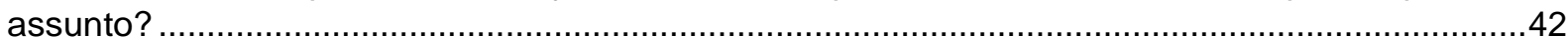

Gráfico 21 - Nos últimos seis meses, você buscou se informar sobre finanças? ................................43

Gráfico 22 - Na sua opinião, qual o melhor meio de se informar sobre finanças? ...............................44

Gráfico 23 - Ainda que você não costume realizar nenhum tipo de planejamento, na sua opinião,

qual o principal motivo que favorece a elaboração de um planejamento financeiro? .....................44 


\section{LISTA DE TABELAS}

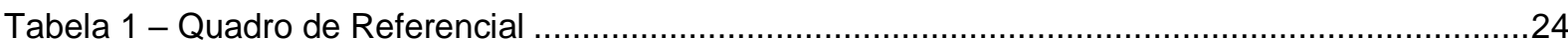

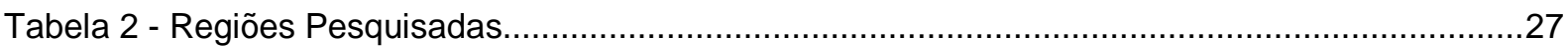

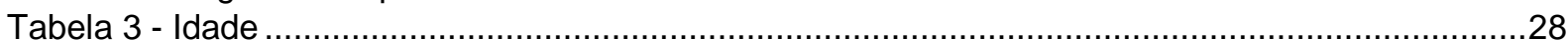

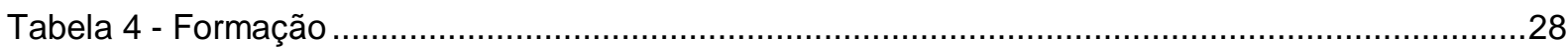

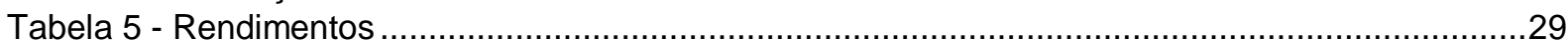

Tabela 6 -Comparativo entre Renda Mensal x pagamento mensal .................................................31

Tabela 7 - Comparativo Reserva x Realização de sonho ...............................................................33

Tabela 8 - Comparativo Orçamento Mensal x Movimentação de Patrimônio ........................................35

Tabela 9 - Comparativo Atitudes de Investimentos x Posição atual de investimento ............................40

Tabela 10 - Opções de Investimento ...................................................................................... 41 
1.... INTRODUÇÃO

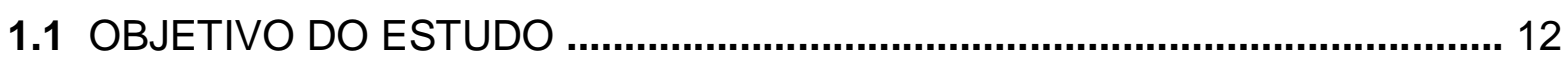

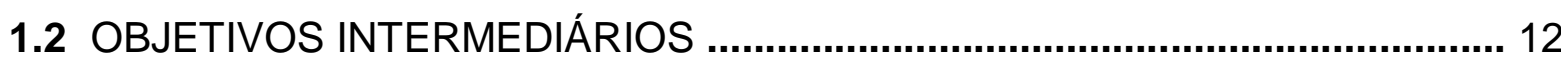

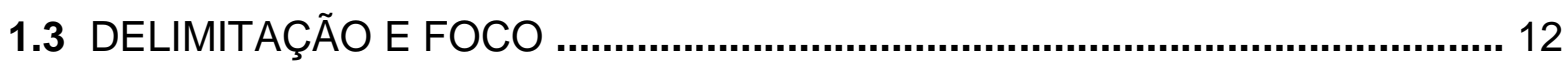

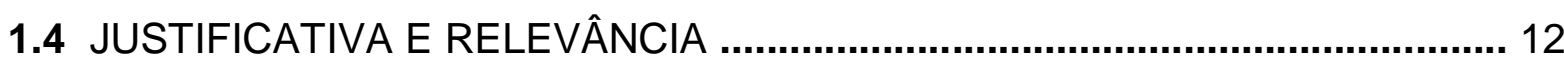

2. REFERENCIAL TEÓRICO ....................................................................... 14

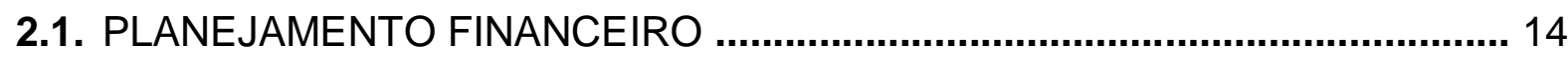

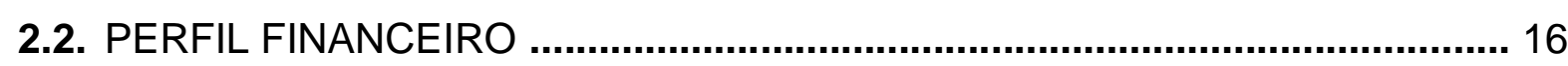

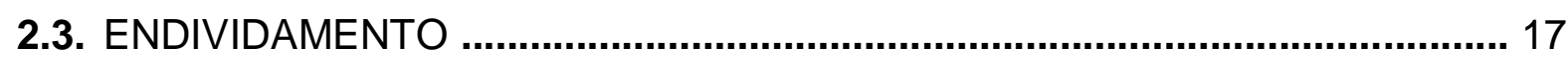

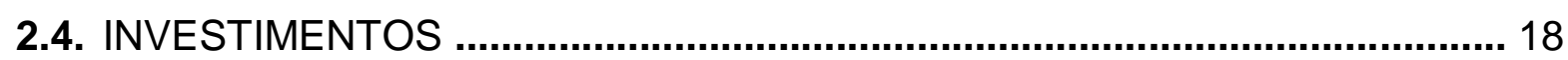

3. MÉTOdOS E PROCEDIMENTOS DE COLETA E DE ANÁLISE DE DADOS

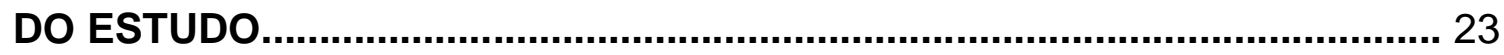

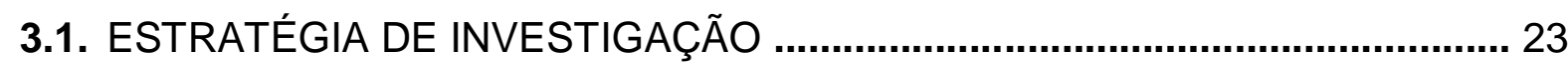

3.2. PROCEDIMENTOS E INTRUMENTOS DE COLETA DE DADOS ................. 23

3.3. FORMA DE TRATAMENTO E ANÁLISE DOS DADOS COLETADOS .......... 24

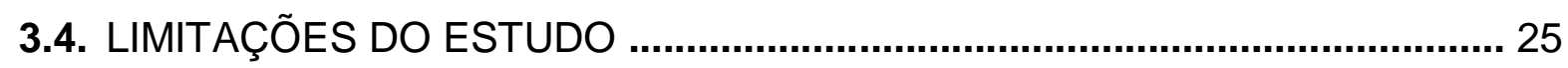

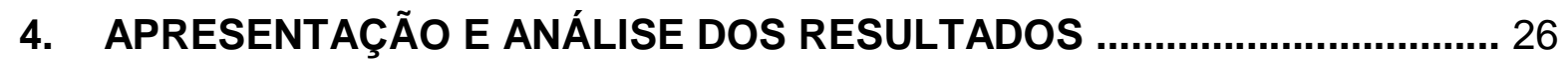

4.1. PERFIL DOS RESPONDENTES ............................................................... 26

4.2. PLANEJAMENTO E CONTROLE FINANCEIRO PESSOAL .......................... 29

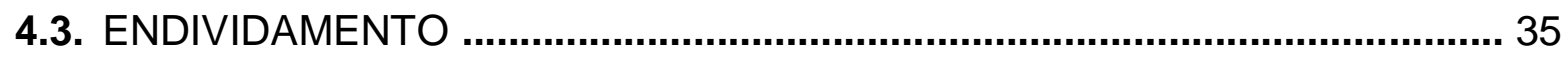

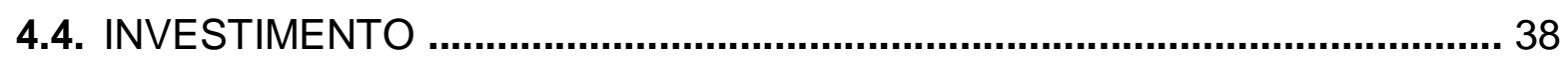

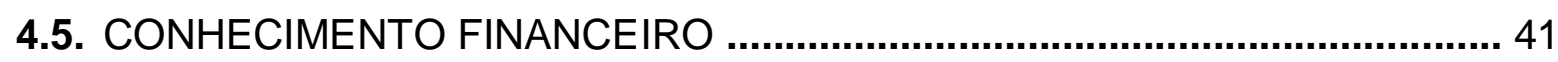

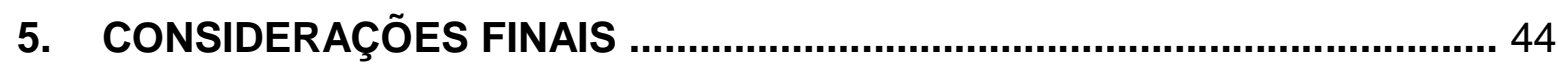

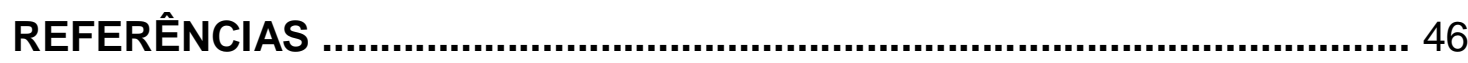

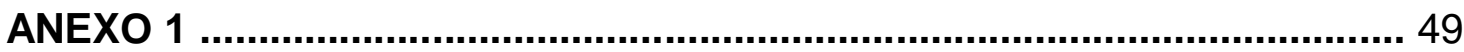




\section{INTRODUÇÃO}

Para os estudiosos de finanças pessoais, quando o assunto se refere à educação financeira, pode-se classificar o Brasil como um país "pobre" no tema em questão. Há inúmeras crenças quando o assunto é dinheiro ou a falta dele; quem tem geralmente é discriminado e quem não tem muitas vezes não se preocupa em economizar. (CERBASI, 2014)

Um levantamento feito em 2016 pela Organização para a Cooperação e o Desenvolvimento Econômico (OCDE), tinha por objetivo medir as competências da população adulta dos 30 países participantes quanto ao tema de educação financeira. A pesquisa levou em consideração três conceitos: atitude, comportamento e conhecimento. Tal pesquisa revelou que o Brasil obteve um índice de 58\%, o deixando na $27^{\circ}$ posição, ficando à frente apenas da Bielorrússia, Polônia e Croácia.

Tais resultados, apenas despontam o que já é conhecido: apesar dos brasileiros já estarem familiarizados com termos relacionados a finanças, o conhecimento real sobre o tema ainda é muito baixo; além de a população possuir uma maior dificuldade no entendimento das questões matemáticas e financeiras, algumas simplesmente não possuem interesse no assunto, o que compromete não somente sua compreensão sobre questões econômicas, mas como também a capacidade de planejar seu futuro e anteceder-se a possíveis imprevistos.

Porém, para procurar entender o porquê de os brasileiros não serem tão envolvidos com a causa financeira, pode-se também tentar compreender o contexto histórico deste país. Isso porque não é de hoje que temas como crise econômica e taxas inflacionadas são vistas e ouvidas frequentemente nos jornais e revistas; Há décadas os brasileiros enfrentam e sofrem as consequências de crises econômicas, o que afeta principalmente em seus orçamentos domésticos. (BRASIL, 2015)

A verdade é que somente após a implantação do Plano Real a economia brasileira começou a firmar-se. Isso ocorreu porque de um modo geral a forma encontrada para forçar a estabilização da economia foi a âncora cambial. Uma consequência do plano foi um alto crescimento da demanda e da atividade econômica. Contratos de trabalho foram formalizados e créditos foram liberados, a parte da população mais pobre começou a consumir exageradamente, pela não 
necessidade de pagamento do chamado "imposto inflacionário", o que aumentou assim o número de endividamento e consecutivamente a inadimplência (Gremaud ET.al. 2007). Nesse contexto histórico, algum conceito - até então não muito completo - sobre finanças pessoais começou a surgir no país.

Todos os meses, a Confederação Nacional do Comércio de Bens, Serviços e Turismo (CNC) realiza uma pesquisa para traçar o perfil e nível de endividamento das famílias brasileiras. Esse estudo, realizado desde 2010, possui como um importante aspecto acompanhar o nível de endividamento e comprometimento dos consumidores/população com suas dívidas e suas percepções em relação à capacidade de pagamento.

Em setembro de 2018, o percentual de famílias endividadas ficou estável em relação ao mês anterior, após duas altas mensais. Segundo a pesquisa, 60,7\% dos entrevistados declaram ter dívidas em contas de cunho doméstico e empréstimos. Além disso, o percentual de famílias que declaram não possuírem condições de pagar suas contas ou dívidas aumentou de 9,8\% (em agosto) para 9,9\%.

Segundo dados do Instituto Brasileiro de Geografia e Estatística (IBGE) divulgado no ano de 2018, o Brasil ultrapassou o número de 208,4 milhões de habitantes. E ainda no ano de 2018 o Tesouro Direito divulgou que em junho, alcançou 834.835 mil investidores cadastrados, porém apenas 306.680 possuem alguma aplicação efetivamente. Em janeiro do mesmo ano, um levantamento da B3 (antiga BM\&F Bovespa) revelou que atingiu o número de 642.3 mil investidores ativos. Diante desses dados, pode se confirmar que a porcentagem de investidores brasileiros ativos ainda é muito baixa perto do total da população. (BRASIL, 2018)

Percebe-se então, que o processo de alfabetização financeira é algo muito complexo e que se mostra de modo completamente diferente diante principalmente de variáveis econômicas e demográficas, visto que países desenvolvidos possuem não somente uma melhor economia, mas como também uma maior capacidade do potencial humano para a aprendizagem de educação financeira, bem como o engajamento de alguns países em desenvolver tal capacidade em sua população. (Savoia ET AL., 2007)

Para fundamentar um pouco essa informação, uma pesquisa realizada em 2019 pelo Serasa Experian explica que: “A análise por faixa etária dá sinais dessa 
constatação. No grupo de pessoas com mais idade (entre 55 e 64 anos), o Indicador de Alfabetismo Funcional vai à contramão do nível de educação financeira.", conforme o gráfico da figura 1.

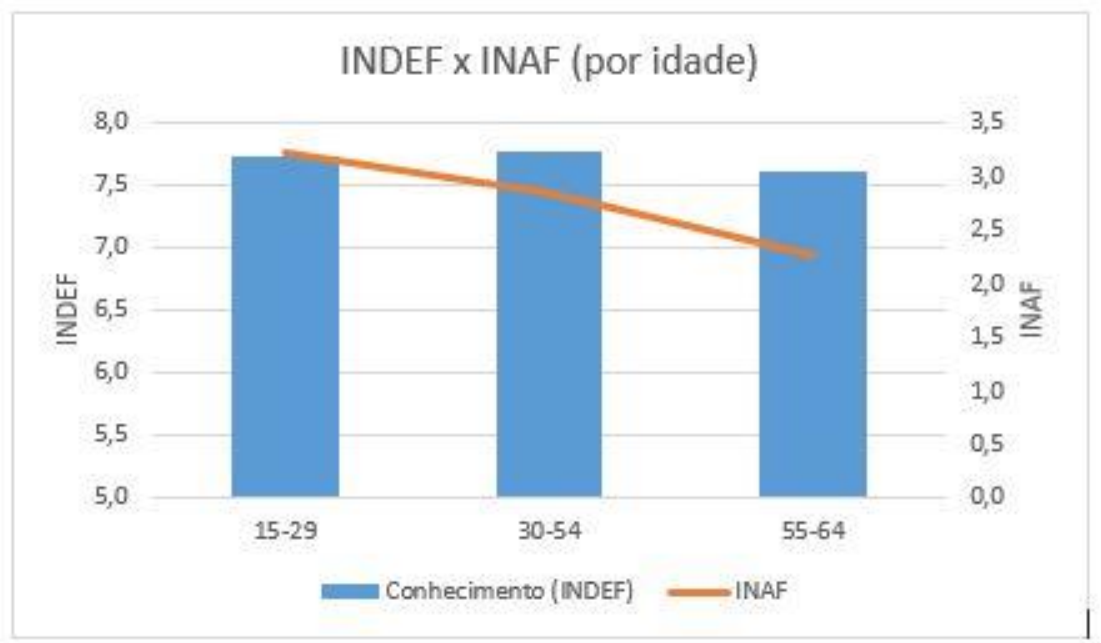

Grafico 2 - Indicador de Alfabetismo Funcional - Conhecimento Fonte: Serasa

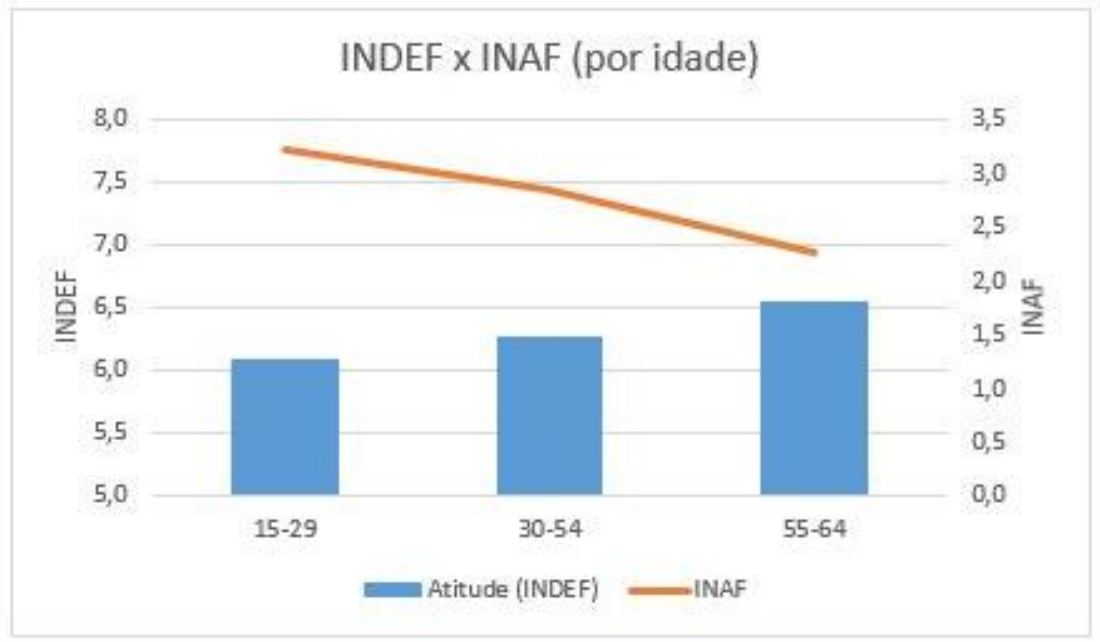

Grafico 3 - Indicador de Alfabetismo Funcional - Atitude Fonte: Serasa

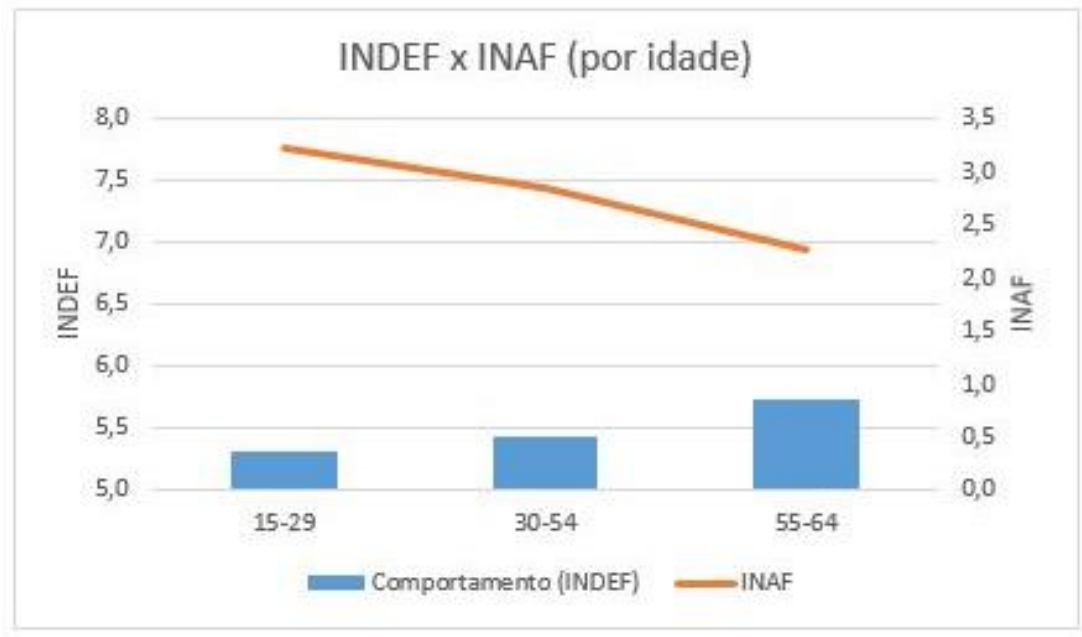

Grafico 1 - Indicador de Alfabetismo Funcional - Comportamento Fonte: Serasa 
Ou seja, uma boa educação, de modo geral, possui um papel fundamental nos processos de desenvolvimento econômico tanto do país quanto do pessoal. Isso porque, esses indivíduos - quando melhor informados - colaboram com o mercado de uma maneira competitiva e eficiente.

Porém, o que se vê, muitas vezes, é que há um consumo exagerado por uma parte da população, e a partir disso começam os problemas financeiros, que são capazes até de intervirem nas motivações e na concentração de um indivíduo. Mas, o que realmente se quer é qualidade de vida, por isso a importância de possuir objetivos bem definidos, e para isso um bom planejamento financeiro é de suma importância. A falta dele é o que acarreta o início dos problemas então citados.

E por isso, é importante que se promova uma reflexão sobre a relação dos brasileiros com o dinheiro e qual a melhor maneira de gerir seu orçamento. Ser alfabetizado financeiramente é saber usar o dinheiro de maneira correta, honrando dívidas, evitando gastos desnecessários e investido para formação de um patrimônio. Esse processo de educação oferece ao indivíduo o conhecimento necessário para tomar decisões financeiras conscientes e responsáveis, e assim fazer presente sua participação no processo de desenvolvimento econômico do país de forma mais alinhada.

A globalização trouxe acesso a informações que há algum tempo atrás apenas os mais privilegiados possuíam (PEREIRA, 2001). Hoje, pode-se encontrar na internet qualquer pergunta que um indivíduo tenha em relação a finanças. Além disso, surgiu na internet também, nos últimos anos, inúmeros influenciadores financeiros que se propõem a ajudar e ensinar a todos sobre economia, finanças pessoais e investimentos.

Porém, apesar disso, e a partir dos dados citados, percebe-se que o Brasil ainda é um país necessitado de mais informações que sejam capazes de mudar o pensamento e modo de agir da população. 


\subsection{OBJETIVO DO ESTUDO}

Diante dos dados apresentados, este presente trabalho pretende responder a seguinte pergunta: qual o nível de entendimento de pessoas economicamente ativa sobre planejamento financeiro?

Sendo assim, o foco deste trabalho é avaliar o nível de educação financeira em um grupo de pessoas e se há alguma inclusão do seu conhecimento sobre finanças em seu orçamento. Isso permite compreender o relacionamento financeiro dessa pequena parte economicamente ativa dos brasileiros.

\subsection{OBJETIVOS INTERMEDIÁRIOS}

Para que o objetivo final possa ser alcançado e assim aproximar-se da resolução do problema de pesquisa acima citado, o estudo passará por etapas denominadas como objetivos intermediários.

> Compreender mediante teste, a relação dos indivíduos com seus recursos financeiros e identificar um perfil financeiro.

Conhecer o perfil financeiro é importante para se ter noção dos hábitos do cotidiano e assim ser possível compreender o porquê de a população não conseguir manter seu orçamento e ser, em partes, endividadas, como citado acima.

$>$ Conhecer os hábitos de poupança e investimento.

Neste objetivo será possível descobrir quais são os principais motivos que impedem a maior parte da população a não economizarem para o futuro.

\subsection{DELIMITAÇÃO E FOCO}

O presente trabalho terá como foco de estudo, os brasileiros acima dos 18 anos e que sejam economicamente ativos na sociedade, ou seja, pessoas que tem potencial de mão de obra. (IBGE, 2018)

\subsection{JUSTIFICATIVA E RELEVÂNCIA}

Ser educado financeiramente é muito importante e não deveria haver problemas para falar sobre dinheiro, pois todos - cedo ou tarde - irão precisar saber lidar com suas finanças, e se todos aprendessem sobre isso, as experiências 
poderiam ser menos traumáticas para alguns indivíduos e também aprenderiam sobre outras oportunidades de ganhar através, como por exemplo, de investimentos. Por isso, estimular o assunto ante a sociedade é relevante, pois quanto mais se fala, maiores são as chances de interesse por parte da população e maior são as chances de tornarem-se pessoas que planejam mais, investem mais e acabam mais responsáveis financeiramente.

Além disso, toda e qualquer contribuição é importante para ajudar a possíveis implementações de novas e mais estratégias que possam surgir para alfabetização financeira dos brasileiros. 


\section{REFERENCIAL TEÓRICO}

\subsection{PLANEJAMENTO FINANCEIRO PESSOAL}

A literatura de planejamento financeiro é vasta nas questões empresariais, por isso, esse tópico irá apresentar as teorias empresariais, para que seja possível a incorporação dessas teorias também voltadas para a aplicação de planejamento pessoal.

Gitman (2001) afirma que um aspecto importante, seja nas operações empresariais ou de simples famílias, é o planejamento financeiro. Este deve mapear caminhos para que se atinja a meta ou objetivo. Controlar, guiar e coordenar determinadas ações são etapas fundamentais para quem deseja atingir uma vida financeira equilibrada. Ainda segundo Gitman (2001, p. 434) "O processo de planejamento financeiro começa com planos financeiros de longo prazo, ou estratégicos, que por sua vez guiam a formulação de planos a curto prazo ou operacionais". Para o autor, os planos de longo prazo costumam cobrir um período de dois a dez anos, e os planos financeiros de curto prazo são projetados para que se alcance uma meta para um período mais curto, de um a dois anos, ambos devem ser alinhados com seus gastos e reflexos financeiros.

Segundo Oliveira (2009), o planejamento é um processo que através dele, pode-se alcançar uma meta de forma eficiente e eficaz, pois há uma apropriada alocação de esforços e recursos necessários para obter o resultado esperado. Ou seja, planejamento financeiro é necessário para que objetivos possam ser alcançados, divididos entre espaços de tempos de curto e longo prazo e também permitindo assim um melhor aproveitamento de seus recursos.

Muitas pessoas pensam que para realizar um planejamento financeiro é necessário o auxílio de um profissional da área, elaboradas ferramentas de análises e dom de prever o futuro. Esse pensamento recorrente - que muitas vezes nasce da dificuldade que algumas pessoas possuem com números e tabelas - aparece porque, infelizmente, no Brasil a educação caminha para se tornar um sistema falido, o que não permite que a educação financeira seja uma realidade nas escolas brasileiras. (CERBASI,2014)

Cerbasi (2014) explica que a tecnologia empregada em um planejamento financeiro utiliza ferramentas de matemática financeira básica, com a utilização de conceitos e fórmulas compatíveis com a vista na matemática de ensino médio. $O$ 
autor acredita que se os casos vistos em sala de aula fossem exemplificados com os casos do cotidiano das famílias brasileiras, uma boa parte dos jovens que ingressam todo ano no mercado de trabalho já teriam ao menos o esboço de planos para sua independência financeira.

No entanto, no país, não existe obrigatoriedade da existir educação financeira no sistema de ensino brasileiro. O MEC (Ministério da Educação e Cultura) recomenda que no ensino da matemática deve-se estimular a capacidade de leitura e interpretação dos textos de conteúdo econômico, estimular a habilidade de analisar cálculos de juros de vendas a prazo e desenvolver o entendimento do relacionamento entre matemática e as demais áreas de conhecimento (economia). Tais recomendações ainda não evidenciam uma preocupação do MEC com a inclusão da educação financeira no ensino da população brasileira.

No Brasil, dentre os órgãos públicos foi criado em 2007 um programa denominado Estratégia Nacional de Educação Financeira (ENEF). O objetivo da ENEF é promover a criação de uma cultura financeira bem elaborada dentro da população. O programa prevê ações para o público já adulto e para escolas, o que segue uma tendência mundial. O programa serve para ampliar a compreensão da população, para que ela seja consciente na hora de decidir quanto à administração dos recursos financeiros e assim colaborar para a solidez e eficiência do mercado financeiro, de capitais, de seguros, de previdência e capitalização.

Para Frankenberg (1999) planejamento financeiro pessoal é: "Estabelecer e seguir uma estratégia precisa, deliberada e dirigida para a acumulação de bens e valores que irão formar o patrimônio de uma pessoa e de sua família. Essa estratégia pode estar voltada para curto ou longo prazo".

E conforme afirma o autor, planejamento financeiro pessoal possui objetivos semelhantes aos objetivos de uma empresa, como crescimento de patrimônio e valorização para os acionistas, assim como um indivíduo almeja para sua família.

Para Cerbasi (2014), o planejamento financeiro não é apenas manter-se acima do vermelho, pois para o autor não devemos somente alcançar um padrão de vida como também mantê-lo, e por isso o planejamento se faz necessário. O autor em seu livro afirma que o segredo é enxergar para onde vai o dinheiro, porque a grande maioria não sabe dizer como gastam e assim não sabem como fazer para sobrar no final do mês. 
Nesse contexto deve-se identificar o grau de endividamento, o perfil financeiro, as possibilidades de investimentos e a quantia monetária que seja considerada necessária deixarem disponíveis. É uma parte do planejamento também e que podem e devem ser modificadas e revisadas de acordo com as necessidades e com as mudanças econômicas, como altas taxas e ajustes fiscais.

\subsection{PERFIL FINANCEIRO}

Cada indivíduo é único, ele tem seu jeito de ser, de agir e de comportar dentro de uma sociedade. Tais aspectos exclusivos de cada um também possuem influência no modo como elas agem em relação ao dinheiro. (ANBIMA, 2018)

Assim, conhecer o próprio perfil é a primeira coisa a se fazer para que se possa ter noção dos próprios hábitos dentro do seu cotidiano. Conhecer a si mesmo pode ser fundamental para ajudá-lo a corrigir fraquezas que impedem o crescimento financeiro pessoal. (CERBASI, 2014)

Em 2018, a Associação Brasileira das Entidades dos Mercados Financeirose de Capitais (Anbima) divulgou um relatório de uma pesquisa realizada onde foi identificado que os brasileiros costumam ter cinco perfis de finanças distintos. São eles:

- Construtor: são os que crescem devagar e sempre. Eles não se importam de poupar aos poucos, são organizados e controlados e sabem lidar com os imprevistos.

- Despreocupado: para eles é importante viver bem e agora. Os indivíduos desse perfil não querem pensar em dinheiro; não necessariamente possuem dívidas, porém consideram o controle de gastos algo trabalhoso e não desejam envolvimento.

- Camaleão: são os que apenas fecham as contas, nem que para isso seja necessário a recorrer a empréstimos. No fim seus recursos servem somente para pagas as contas e não sobra nada para investir.

- Sonhador: são os motivados pelo futuro, são ambiciosos, mas não pensam no dia a dia. Crêem que precisam de muitos para investir e tirar seus sonhos do papel. 
- Planejador: calculam suas metas de crescimento. Os planejadores possuem metas bem definida, são atentos as oportunidades e maximizam seus recursos. No dia a dia, sempre tomam decisões para estarem sempre alinhados com suas metas.

\subsection{ENDIVIDAMENTO}

O indivíduo que faz uso de recursos financeiros para a aquisição de um bem, pode se endividar e o exagero de dívidas pode levar o consumidor ao estado de inadimplência, que é caracterizado quando o mesmo não consegue pagar um compromisso financeiro até a data de seu vencimento (PLACEDINO, 2009). Ou seja, uma pessoa endividada é aquela que não consegue arcar com suas despesas financeiras. Para Tolotti (2007), o atraso necessário para uma pessoa ser considera inadimplente varia de um a três meses.

Um relatório divulgado pela Confederação Nacional de Comércio de Bens, Serviços e Turismo em abril de 2019, revelou que o percentual de famílias que relataram estar endividadas foi de $62,7 \%$ um aumento de quase um por cento em relação a fevereiro do mesmo ano. Segundo o relatório, o cartão de crédito foi indicado por $77,6 \%$ como o primeiro tipo de endividamento das famílias brasileiras, seguido de carnês para $15,3 \%$ e por financiamento de automóvel por 10\%. Diante dos dados apresentados no acima, o que vemos na sociedade atual é que o brasileiro possui certa dificuldade a planejar e organizar suas finanças e suas ações sejam elas a curto ou longo prazo.

O país, também incapaz de diminuir suas contas e realizar investimentos necessários capazes de impulsionar o crescimento, buscou nos últimos anos assim como na implementação do Plano Real - ampliar a oferta de crédito para o incentivo de consumo de bens e serviços, para estimular assim o aumento de produção. Apesar desse estímulo ter aspectos positivos, pois o aumento de crédito viabiliza uma produção de riqueza, pode-se também alavancar a economia e incluir a parte da população mais desfavorecida (MATTAR et al, 2006).

Porém, o que vemos diante dos dados (apresentados na introdução) é que a falta de preparação da população, que desesperada e endividada, costuma buscar no crédito fácil formas de restaurar seu equilíbrio financeiro. Esse aumento desorientado produz assim a inadimplência e então os créditos são interrompidos. 
Em consequência a economia reduz as atividades, e assim surge o ciclo vicioso de expansão e retração do crescimento. (GREMAUD, 2007)

Para Cerbasi (2014), a maioria dos problemas financeiros decorre de escolhas e decisões ruins de um indivíduo. O autor explica que para ele, as dificuldades enfrentadas não é somente culpa de altas taxas de juros bancárias, mas de um padrão de vida elevado demais para aquela pessoa ou família, que ao invés de ajustarem seus gastos, preferem somente não se preocupar com o futuro. Assim, considerando que essas escolhas financeiras não são movidas somente pela racionalidade, o endividamento é visto como o resultado de uma gestão financeira ruim e como resultado de motivações emocionais (TOLOTTI, 2007).

\footnotetext{
"De modo geral, um consumidor educado financeiramente planeja adequadamente seus gastos, pesquisa e compara preços para aumentar seu poder de compra, estimulando o desenvolvimento e a livre concorrência e contribuindo para controle da inflação". (ARAUJO, et al., 2012)
}

A boa Educação Financeira está no equilíbrio. O consumidor consciente sabe contrabalançar suas necessidades com sua realidade, sabe direcionar recursos para as contas e gerar reservas. Isso porque economizar e guardar dinheiro são decisões inteligentes para quem tem planos futuros e desejos a realizar, e assim possa viver livre de preocupações (BARRATO et al., 2006).

\subsection{INVESTIMENTOS}

Define-se investimento como aplicações dos recursos de um indivíduo, seja dinheiro ou títulos de crédito. Se realizado de modo correto e sensato, essa aplicação é capaz de gerar um retorno, no futuro, maior do que o esperado. Pois é acumulado através dos rendimentos financeiros que somente geram acúmulo se mantiver um período considerável na aplicação (GITMAN, 2001).

A impossibilidade de realizar transações durante o período em que o recurso está aplicado compensa o tempo de espera (GITMAN, 2001).

Aplicar recursos através da aquisição de bens como à compra de veículos, terrenos ou imóveis também podem ser considerado investimento, porém, espera-se que essas aplicações tragam retorno, pois o investidor aplicou seus recursos sobre eles. O que pode não acontecer se o indivíduo não souber realizar tais transações. 
De modo geral, os investimentos são meios que buscam rentabilidade futura (CERBASI, 2014).

Frankenberg (1999), afirma que realizar aplicações pode ser uma difícil tarefa, isso porque, dependendo da situação do investidor, os recursos separados para aplicação em investimentos podem ser altos, e se o investidor não sentir a segurança necessária, isso o deixa mais suscetível a incertezas quanto a arriscar seus recursos, devido à importância de um alto montante. Porém, aversão aos riscos de mercado pode significar perda, pois ele perde a possibilidade de aplicar recursos - para que esse seja capaz de gerar maiores ganhos mesmo estando parados - e benefícios, como a independência financeira.

Uma pesquisa realizada anualmente pela Anbima, em conjunto com 0 Datafolha, em suas edições, busca acompanhar a evolução de alguns indicadores a fim compreender se a população guarda informações a respeito da economia, da política e de educação financeira. A segunda edição da pesquisa, realizada em 2018, traz informações importantes em relação a aposentadoria, ao modo de guardar dinheiro e os investimento dos brasileiros.

Segundo o relatório, em 2018, 33\% dos brasileiros conseguiram economizar e guardar dinheiro (apenas um ponto percentual a mais do que no ano anterior). Dentre os motivos que colaboraram para esse economia, $71 \%$ afirma que foi devido a cortes desnecessários realizados em suas rotinas e apenas $13 \%$ diz que planejou e economia, fosse guardando o que sobrava no final do mês ou de modo mais organizado, reservando sempre uma porcentagem do salário.

Desses 33\% que economizaram em 2018, 48\% aplicaram em produtos financeiros. Abaixo segue um gráfico com o destino escolhido pelos brasileiros para o dinheiro economizado. 


\section{Destinos escolhidos por quem economizou em 2018}

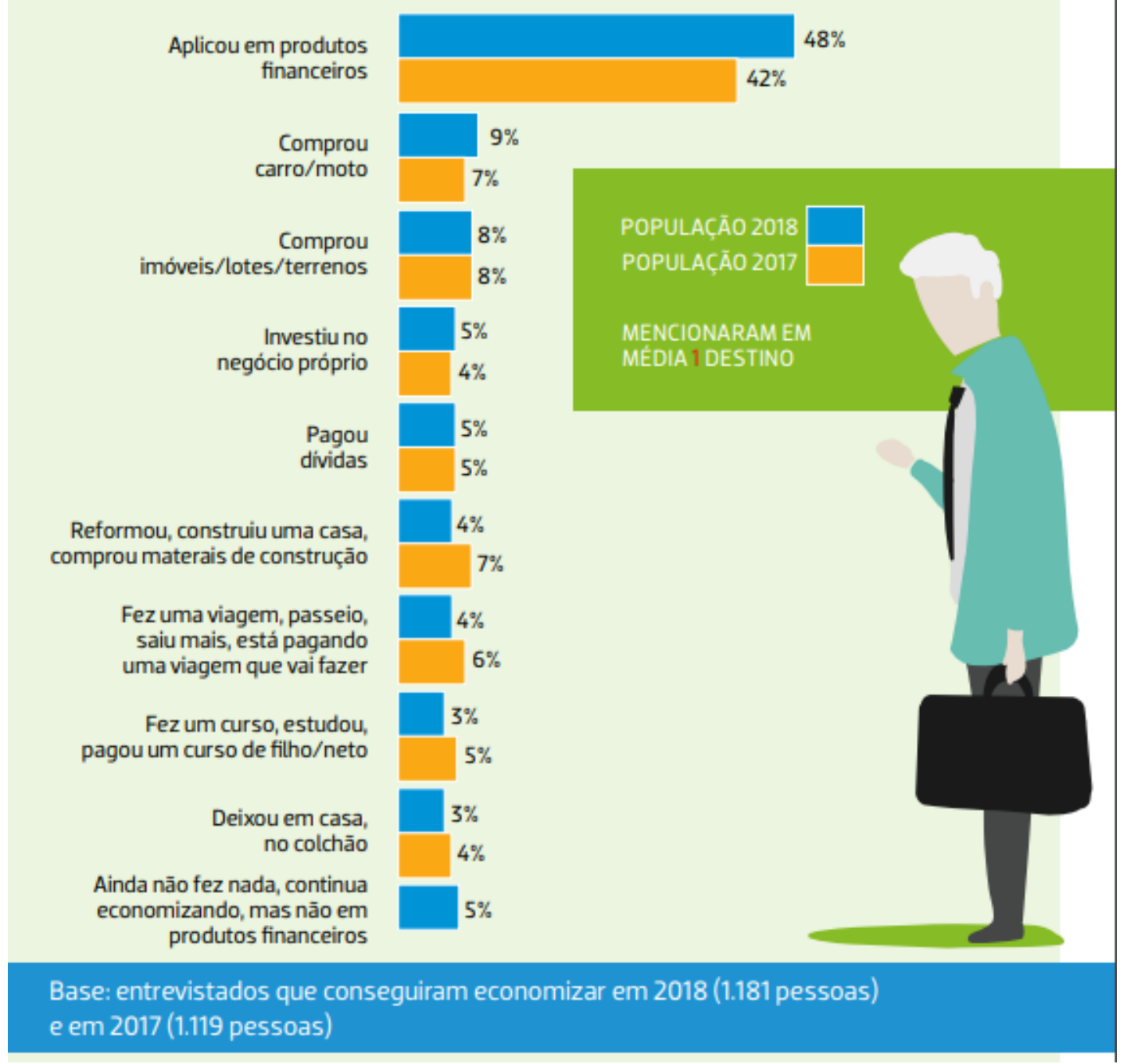

Grafico 4 - Destino de Investimento

Fonte: Anbima

Essa pesquisa também mede o conhecimento da população em relação a investimentos. Esse questionamento é necessário para mensurar o que os brasileiros entendem por investimento. Os testes foram aplicados para avaliar 0 conhecimento espontâneo, ou seja, eram questões abertas onde a amostra mostrava seu conhecimento sobre o assunto e o conhecimento estimulado, onde foram aplicadas perguntas com alternativas. No segundo caso (Gráfico 5), notou-se um aumento em relação às respostas espontâneas. Apesar de serem citados alguns produtos de investimento, há ainda uma diferença entre os que conhecem e os que investem. 


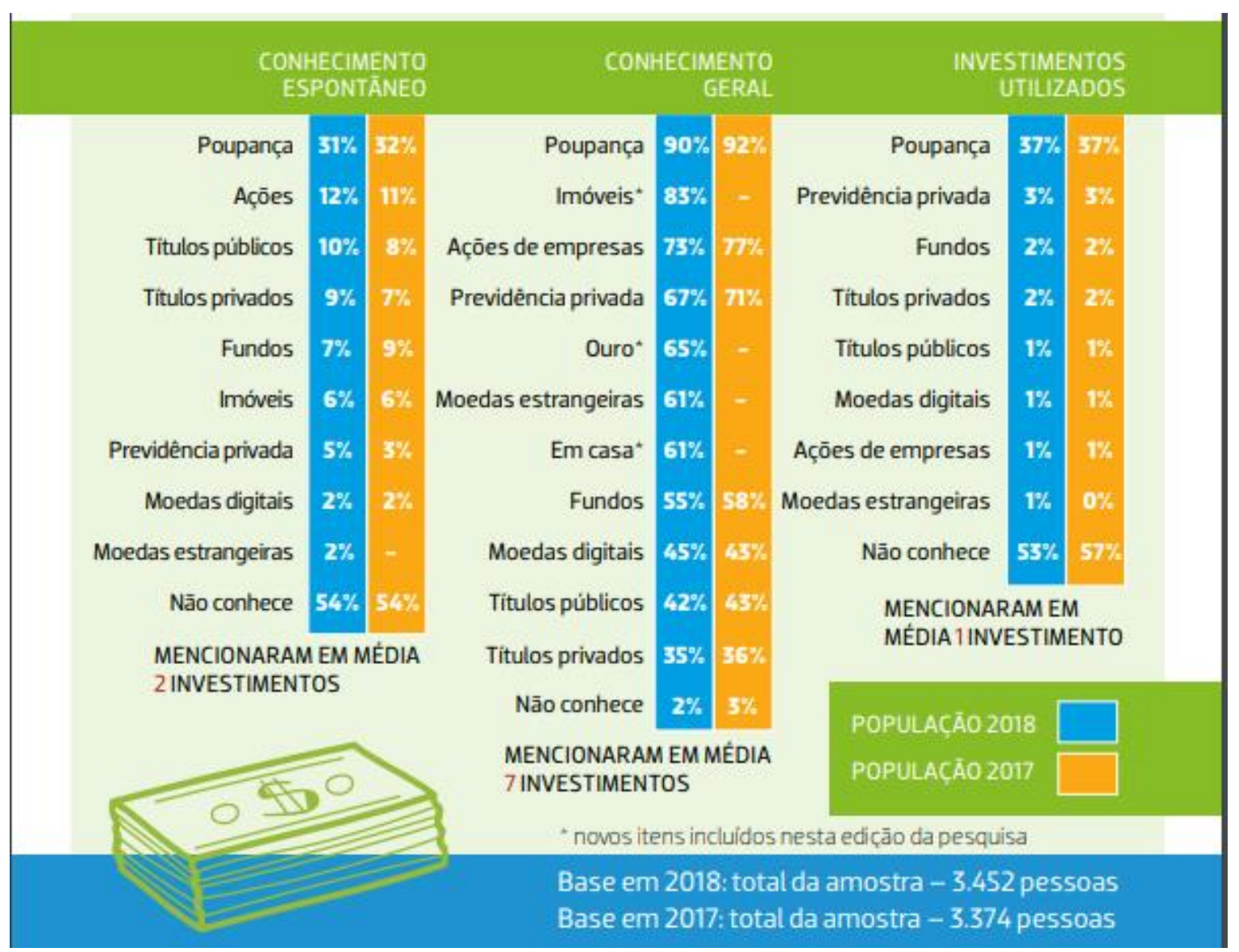

Grafico 5 - Destino de Investimento

Fonte Anbima

"A poupança continua sendo o produto preferido entre os investidores: $88 \%$ dos brasileiros guardam dinheiro na caderneta. A aplicação tem aderência, principalmente, entre quem tem entre 25 e 59 anos, com ensino médio (49\%), os pertencentes à classe C, e os moradores do Sudeste (53\%)." (ANBIMA)

No Gráfico 6, a segurança aparece em primeiro lugar para $48 \%$ dos entrevistados. Ou seja, eles priorizam a segurança em perda do quanto o dinheiro pode render. 


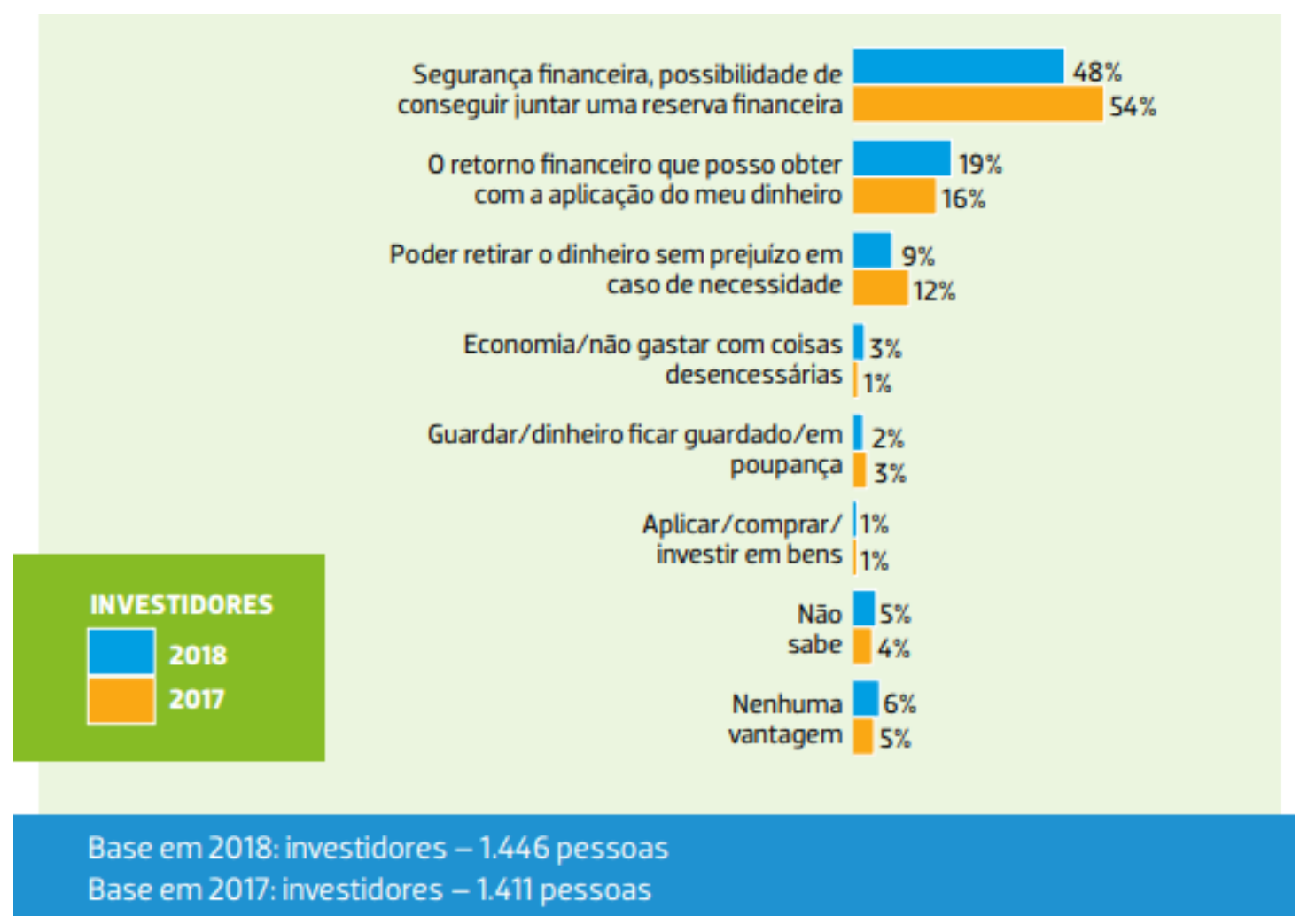

\section{Grafico 6 - Vantagens para Investir}

Fonte Anbima

Para Assaf Neto (2008) gestão dos investimentos é uma tarefa de suma importância, pois ela deve ser realizada de forma eficaz e eficiente. Através dela é realizada a administração dos créditos (valor determinado aos investimentos) de modo que seja possível obter as melhores decisões no que tange à escolha de um investimento e assim, através dele, obter o sucesso financeiro pessoal e a independência financeira esperada. 


\section{MÉTODOS E PROCEDIMENTOS DE COLETA E DE ANÁLISE DE DADOS DO ESTUDO}

Este capítulo traz informações sobre a forma como foi realizada a pesquisa, que tinha como objetivo identificar a relação das pessoas com o conhecimento das suas finanças pessoais, para assim ser capaz de compreender melhor como as pessoas costumam lidar com seu dinheiro.

\subsection{ESTRATÉGIA DE INVESTIGAÇÃO}

A utilização de uma pesquisa exploratória, segundo Gil (1999), é permitir que novas informações possam ser abordadas e compreendidas, e assim esclarecer conceitos para que hipóteses ou questões possam ser mais bem definidas e assim abordadas em outros estudos. Uma pesquisa descritiva, para Gil (1999), tem como principal objetivo expor a característica de uma população ou de um fenômeno, para que se possa identificar, relatar e comparar.

Para medir o nível de entendimento da população, a autora optou por realizar uma pesquisa quantitativa, exploratória e descritiva, pois um dos pontos de pesquisa deste é exatamente, segundo por definição, identificar as características da população.

\subsection{PROCEDIMENTOS E INTRUMENTOS DE COLETA DE DADOS}

As informações e dados necessários para a elaboração da pesquisa foram obtidos através de fontes primárias. Para a preparação do referencial teórico foram consultados relatórios de instituições financeiras e incubadoras, livros, artigos e teses. Todas as pesquisas realizadas foram fundamentais para que fosse possível aprofundar não somente o estudo sobre o tema, mas como também foi um importante auxiliador na preparação do questionário aplicado para a conclusão deste trabalho.

Para que isso fosse possível, foi organizado um quadro de referências como base do questionário, com os conceitos abordados e seus autores correspondentes. 
Tabela 1 - Quadro de Referencial

\begin{tabular}{|c|c|c|c|}
\hline 1 & Perfil financeiro e disponibilidades & Anbima & 2018 \\
\hline 2 & Endividamento & & \\
\hline & Busca de crédito & Gremaud & 2007 \\
\hline & Problemas financeiros & Cerbasi & 2014 \\
\hline 3 & Investimentos & & \\
\hline & Retorno no futuro e tempo de espera & Gitman & 2001 \\
\hline & Bens matérias como investimentos & Gitman & 2001 \\
\hline & Aversão a Riscos & Frankberg & 1999 \\
\hline & Gestão de investimentos & Assaf Neto & 2008 \\
\hline 4 & Planejamento Financeiro & Cerbasi & 2014 \\
\hline & Estratégia de longo prazo & Frankberg & 1999 \\
\hline & Estratégia de curto prazo & Frankberg & 1999 \\
\hline
\end{tabular}

Fonte: Própria

Após essa etapa, foram elaboradas, identificadas e adaptadas questões que fossem mais adequadas ao objetivo do estudo.

No intuito de verificar se as questões iriam funcionar de modo adequado ao trabalho e se seria do entendimento de todos os respondentes, foi realizado um préteste. Este foi passado a cinco pessoas a fim de testar a compreensão e a interpretação das questões em si; assim foi possível identificar possíveis erros que atrapalhassem o andamento da pesquisa, como por exemplo, opções onde os respondentes não se sentiam encaixados e problemas com falta de clareza em algumas das questões.

Depois que os erros foram ajustados, o questionário final ficou elaborado com 22 questões dividas em cinco seções: a primeira delas respondia dados sobre informações pessoais, a segunda seção abordava questões voltadas ao planejamento financeiro do respondente, seguida por uma seção de questões sobre endividamento, outra de investimento e por último, uma seção sobre a busca de conhecimento financeiro.

Assim, a etapa de pesquisa foi realizada através da aplicação de um questionário on-line de perguntas fechadas através da plataforma do Google Forms, a pessoas identificadas como público alvo do trabalho. Considerado a parte da população a partir de 18 anos economicamente ativa, que tenha alguma renda e aposentados. 


\subsection{FORMA DE TRATAMENTO E ANÁLISE DOS DADOS COLETADOS}

$\mathrm{Na}$ etapa da coleta de dados, foram obtidos os dados quantitativos através de uma pesquisa descritiva com questões do tipo múltipla escolha. O tipo de questionário foi escolhido por ser possível realizar uma comparação mais simples entre as respostas, sendo fundamental para a precisão na hora de conclusão do estudo.

O tratamento dos dados foi realizado de dois modos: uma por meio da análise dos questionários, onde serão observadas as respostas como um todo, ou seja, como a amostra se comporta diante das situações que foram apresentadas; e da análise das respostas individuais perante as mesmas situações apresentadas, para que assim possa ser possível realizar comparações e análises mais profundas sobre o comportamento financeiro dos respondentes.

Assim, através das informações fornecidas, será possível realizar um compilado com as partes mais significativas e relacioná-las com o referencial teórico, para que assim o objetivo do estudo possa ser alcançado.

\subsection{LIMITAÇÕES DO ESTUDO}

Ao longo do processo de pesquisa, limitações foram identificadas.

Em relação à parte exploratória, a maior parte da limitação gira em torno do baixo número de amostras e o seu viés. A grande maioria dos selecionados foram de círculos próximos, não somente da autora, mas como também de seus amigos e familiares. Além disso, por se tratar de uma pesquisa que não é assegurada a nenhum tipo de dependência demográfica, trabalhou-se com a hipótese de atingir um público além do Rio de Janeiro, buscando assim, que fosse possível compreender também como a temática de finanças pessoais costumam ser encaradas em outras regiões do país. Porém, não foi possível alcançar o efeito esperado no que tange essa parte, pois o resultado de respostas de outras regiões foi de apenas $17,9 \%$ do total de respondentes.

Além disso, por se tratar de um assunto não muito recorrente e talvez também não interessante para algumas pessoas, muitas delas, quando questionadas já fora do ambiente de pesquisa, apresentaram certo receio quanto ao 
tema. Isso porque, no dia a dia, é que qualquer assunto relacionado ao ambiente financeiro é visto com certo tabu, onde somente os mais privilegiados possuem acesso ao conhecimento e também possuem maiores recursos. Assim, o trabalho de coleta foi demorado para que fosse alcançado um número considerado adequado para uma análise mais completa, possivelmente abrangente e sem muitas margens para erros. 


\section{APRESENTAÇÃO E ANÁLISE DOS RESULTADOS}

Neste capítulo serão apresentados e discutidos os resultados obtidos através da pesquisa realizada - de cunho quantitativo - como já mencionada anteriormente. O capítulo será estruturado em cinco seções, assim como na pesquisa, compreendendo alguns dados dos respondentes, questões sobre planejamento financeiro, endividamento, investimentos e conhecimento financeiro.

\subsection{PERFIL DOS RESPONDENTES}

Dos 106 respondentes, 82,10\% correspondia à região sudeste do país como mostra a tabela 2.

Tabela 2 - Regiões Pesquisadas

\begin{tabular}{ccc}
\hline & Frequência & Percentual \\
Norte & 5 & $4,70 \%$ \\
Nordeste & 5 & $4,70 \%$ \\
Centro-oeste & 6 & $5,70 \%$ \\
Sudeste & 87 & $82,10 \%$ \\
Sul & 3 & $2,80 \%$ \\
Total & $\mathbf{1 0 6}$ & $\mathbf{1 0 0 , 0 0 \%}$ \\
\hline
\end{tabular}

Fonte própria

No que corresponde à faixa etária, observa-se na tabela 3 que a maioria dos respondentes $(59,4 \%)$ tem entre 22 e 39 anos. Foram considerados indivíduos economicamente ativos com 18 anos ou mais. Pela amostra ser de círculos próximos da autora, esse critério já foi identificado antes da pesquisa ser enviada aos respondentes. 
Tabela 3 - Idade

\begin{tabular}{ccc}
\hline & Frequência & Percentual \\
Até 21 anos & 5 & $4,70 \%$ \\
De 22 a 39 anos & 63 & $59,40 \%$ \\
De 40 a 52 anos & 25 & $23,60 \%$ \\
De 53 a 72 anos & 13 & $12,30 \%$ \\
$\quad$ Total & $\mathbf{1 0 6}$ & $\mathbf{1 0 0 , 0 0 \%}$ \\
\hline Fonte própria & &
\end{tabular}

Por se tratar de um estudo sobre educação, foi considerado relevante conhecer sobre a escolaridade dos respondentes, a tabela 4 ilustra a formação dos indivíduos. Nota-se que $65,1 \%$ possuem formação superior.

\begin{tabular}{|c|c|c|}
\hline & Frequência & Percentual \\
\hline Fundamental incompleto & 2 & $1,90 \%$ \\
\hline Fundamental completo & 1 & $0,90 \%$ \\
\hline Médio incompleto & 3 & $2,80 \%$ \\
\hline Médio completo & 9 & $8,50 \%$ \\
\hline Superior incompleto & 22 & $20,80 \%$ \\
\hline Superior completo & 69 & $65,10 \%$ \\
\hline Total & 106 & $100,00 \%$ \\
\hline
\end{tabular}

Em sequência, foram questionados sobre sua renda. Assim, por meio da informação recebida, na tabela 5 é possível observar que a maioria dos respondentes, ou seja, $47,2 \%$ recebe até $R \$ 2.994$ reais; $17 \%$ recebe entre $R \$ 2.994$ e $R \$ 5.998$; e $35,8 \%$ recebe $R \$ 5.998$ reais ou mais. 
Tabela 5 - Rendimentos

\begin{tabular}{ccc}
\hline & Frequência & Percentual \\
Até 3 salários & 50 & $47,2 \%$ \\
De 3 a 6 salários & 18 & $17 \%$ \\
Mais de 6 salários & 38 & $35,8 \%$ \\
Total & 106 & $\mathbf{1 0 0 , 0 0 \%}$ \\
\hline Fonte própria & &
\end{tabular}

Fonte própria

Além disso, os respondentes foram questionados sobre como eles se sentem em relação aos seus ganhos. Assim, seria possível analisar o porquê, mesmo daqueles que se sentem insatisfeitos com seus ganhos, não buscarem outras formas de rendimentos. Como visto no gráfico 7 , a grande maioria $(43,8 \%)$ não se sente nem satisfeita, nem insatisfeita com sua renda mensal, o que ao primeiro momento, demonstra que eles consideram adequados seus ganhos, mas também alerta sobre o que vemos em nosso dia-a-dia, que um grande número de brasileiros não costumam pensar no quanto irão ganhar a longo prazo.

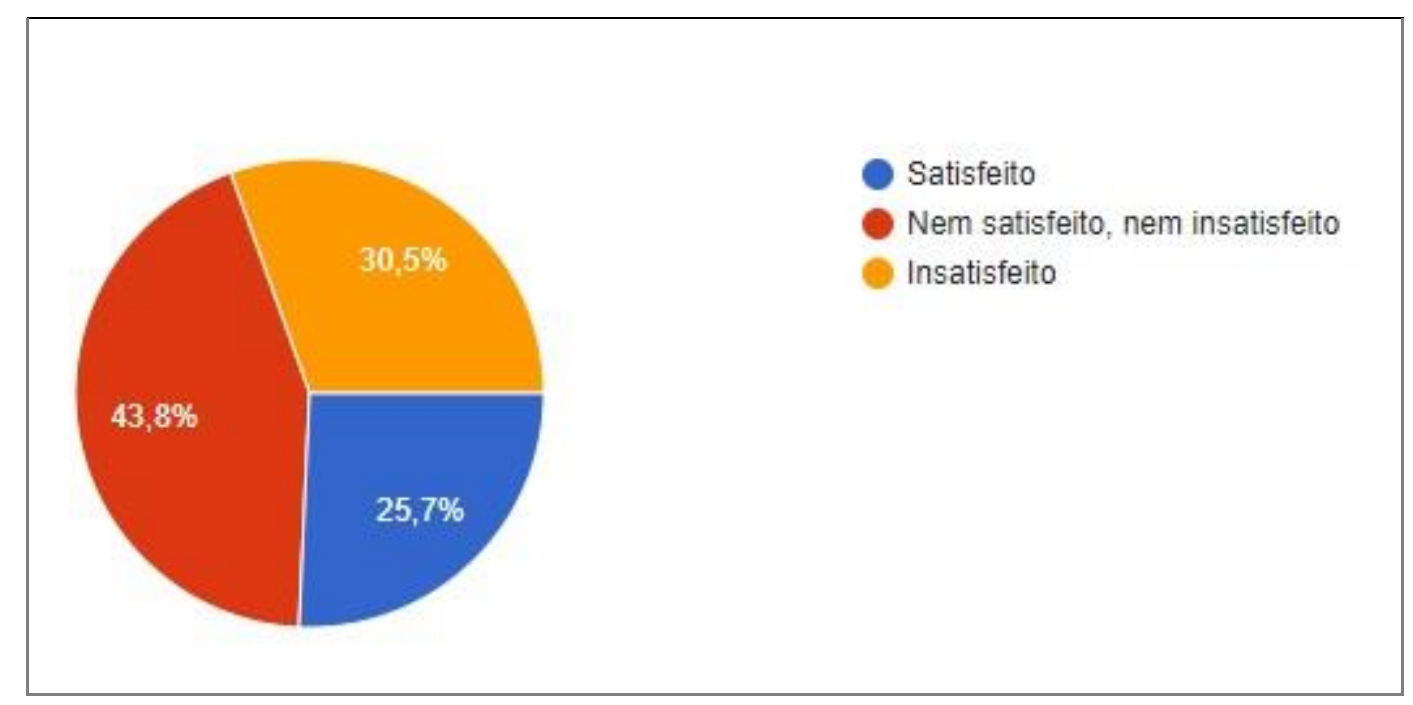

Gráfico 7 - Incluindo todas as suas fontes de renda, você se sente com seus ganhos? Fonte: Própria 


\subsection{PLANEJAMENTO E CONTROLE FINANCEIRO PESSOAL}

Para Cherobim e Espejo (2010), as dívidas, mesmo que grandes ou pequenas, próximas do vencimento ou já vencidas, devem ser separadas em categorias e separadas em uma planilha de orçamento pessoal. Desse modo, no segundo bloco, os respondentes foram questionados sobre o costume de realizar algum tipo de orçamento doméstico e assim, buscar compreender como a amostra pesquisada costuma planejar a vida financeira.

Primeiramente, eles foram questionados sobre a renda mensal e se ela é suficiente para arcar com todas as despesas do mês. O gráfico abaixo mostra como a amostra pesquisada costuma lidar com sua renda mensal.

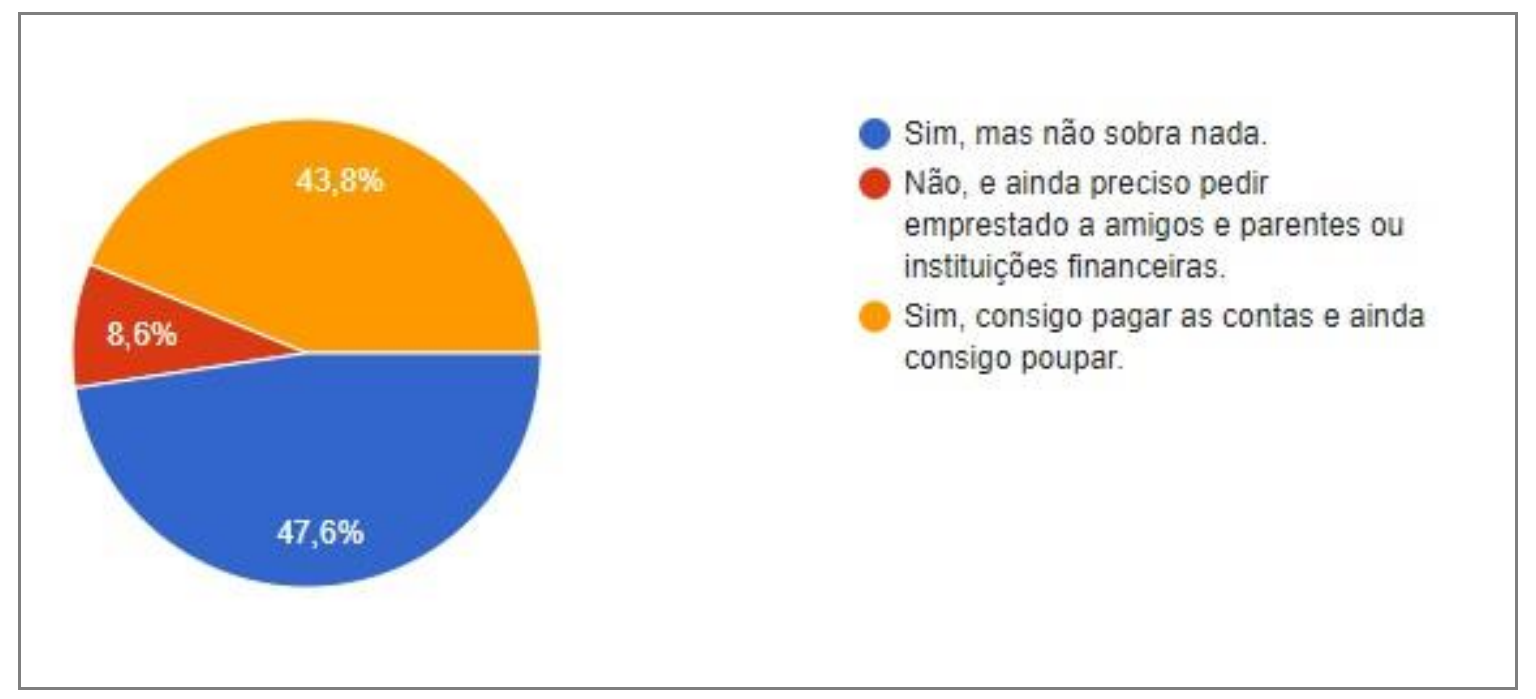

Gráfico 8 - A sua renda mensal é suficiente para arcar com todas as despesas do mês? Fonte: Própria

Em seguida, foram questionados sobre o costume de realizar o orçamento mensal. Nota-se no gráfico 9 que $41,5 \%$ praticam periodicamente um planejamento e acompanhamento dos seus orçamentos. 


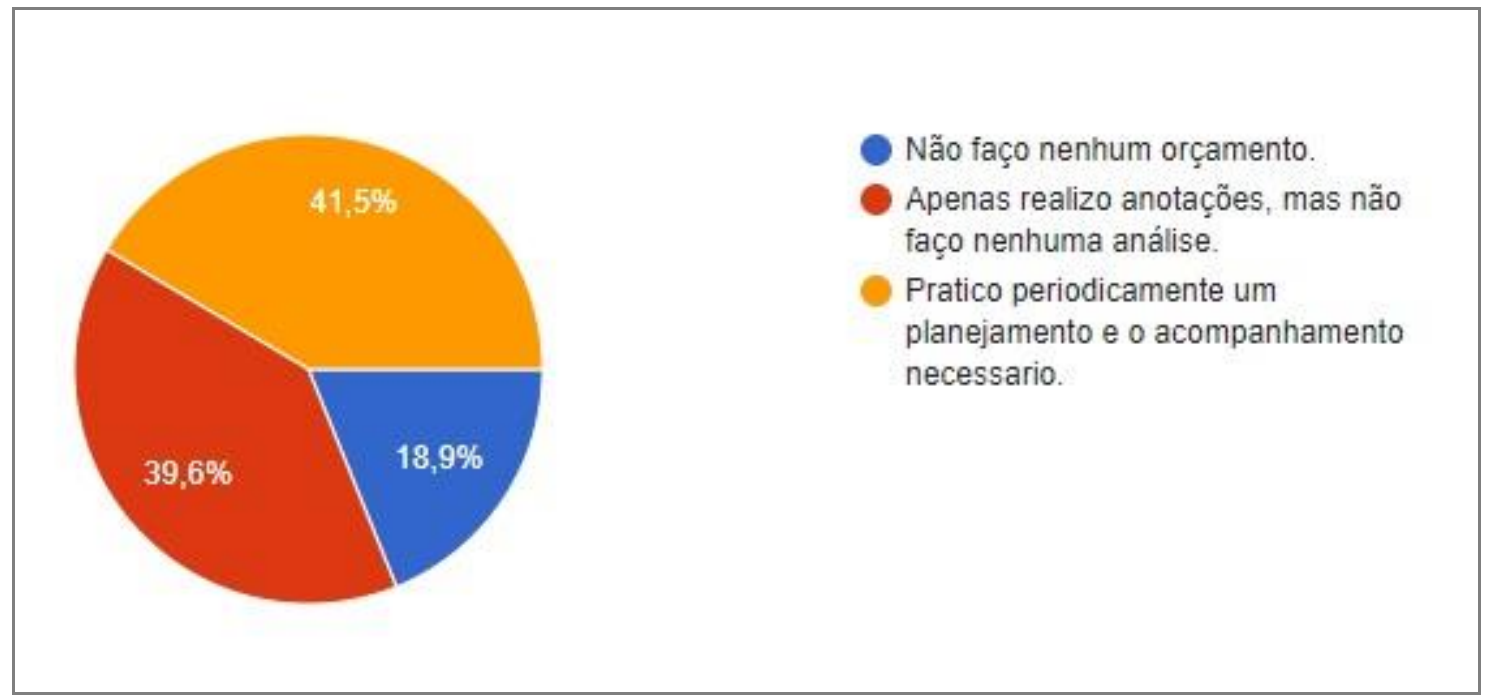

Gráfico 9 - Você realiza algum orçamento mensal?

Fonte: Própria

Dos $18,9 \%$ que não praticam nenhum tipo de orçamento, $35 \%$ (menos da metade), conseguem pagar suas dívidas e poupar; $10 \%$ precisam recorrer a terceiros e $55 \%$ afirmam que pagam suas contas, mas que não conseguem guardar dinheiro.

Dentre aqueles que apenas realizam anotações, 50\% afirmam que conseguem pagar suas contas e poupar; $40 \%$ arcam com suas despesas, porém não conseguem economizar e 10\% afirmam ainda precisarem de ajuda. Além disso, dentre os que praticam periodicamente um planejamento financeiro, 52,3\% apesar de arcarem com seus gastos não conseguem poupar.

A tabela 6 representa os dados citados acima.

Tabela 6 -Comparativo entre Renda Mensal x pagamento mensal

\begin{tabular}{|c|c|c|c|c|}
\cline { 3 - 5 } \multicolumn{2}{c|}{} & \multicolumn{3}{c|}{ A sua renda mensal é suficiente para arcar com todas as } \\
despesas do mês?
\end{tabular}




\begin{tabular}{|c|c|c|c|c|}
$\begin{array}{c}\text { Pratico periodicamente um } \\
\text { planejamento e o } \\
\text { acompanhamento necessário. }\end{array}$ & 44 & 3 & 18 & 23 \\
\hline Totais & 106 & 9 & 46 & 51 \\
\hline
\end{tabular}

Fonte própria

O gráfico 10 apresenta as respostas dos indivíduos quando perguntados se eles possuem algum fundo de reserva e se estariam preparados para um possível imprevisto e qual seria o impacto em sua vida. A grade maioria acredita que realizando cortes e ajustes, são capazes de se esquivar de possíveis os imprevistos que possam ter ao longo de sua jornada e 16\% além de não possuírem uma reserva, não saberiam como começar a resolver esses problemas. Além disso, $30,2 \%$ (32 respondentes) estariam tranquilos mediante um imprevisto.

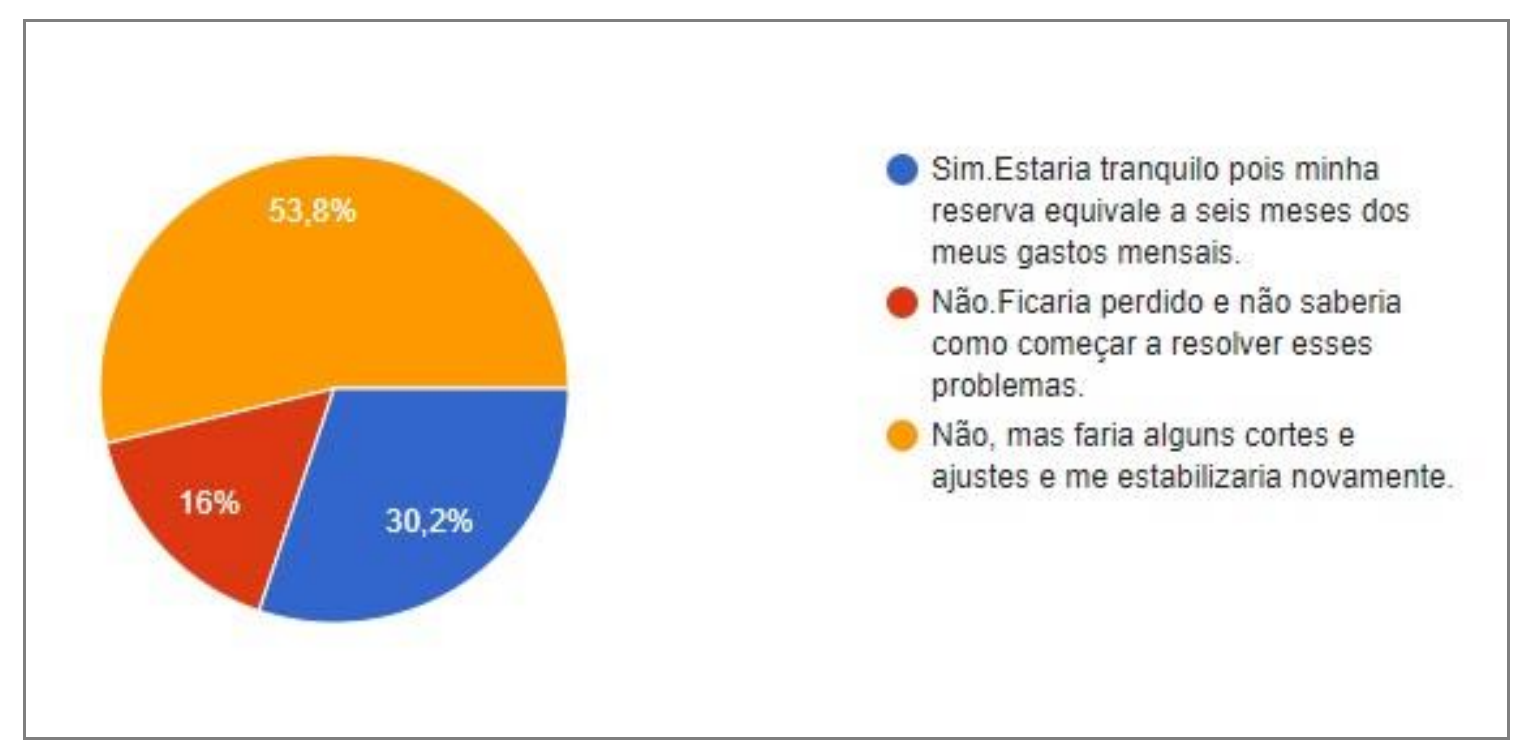

Gráfico 10- Você possuiu algum tipo de reserva? Caso ocorra um imprevisto, qual seria o impacto dele na sua vida financeira?

Fonte: Própria

Eles também foram questionados sobre sonhos e desejos de curto e longo prazo e se eles saberiam como realizá-los. A maior parte dos respondentes, 44,8\% afirmam que sabem exatamente quanto seus sonhos custam e qual o caminho é necessário seguir para que seja possível alcançá-lo. 


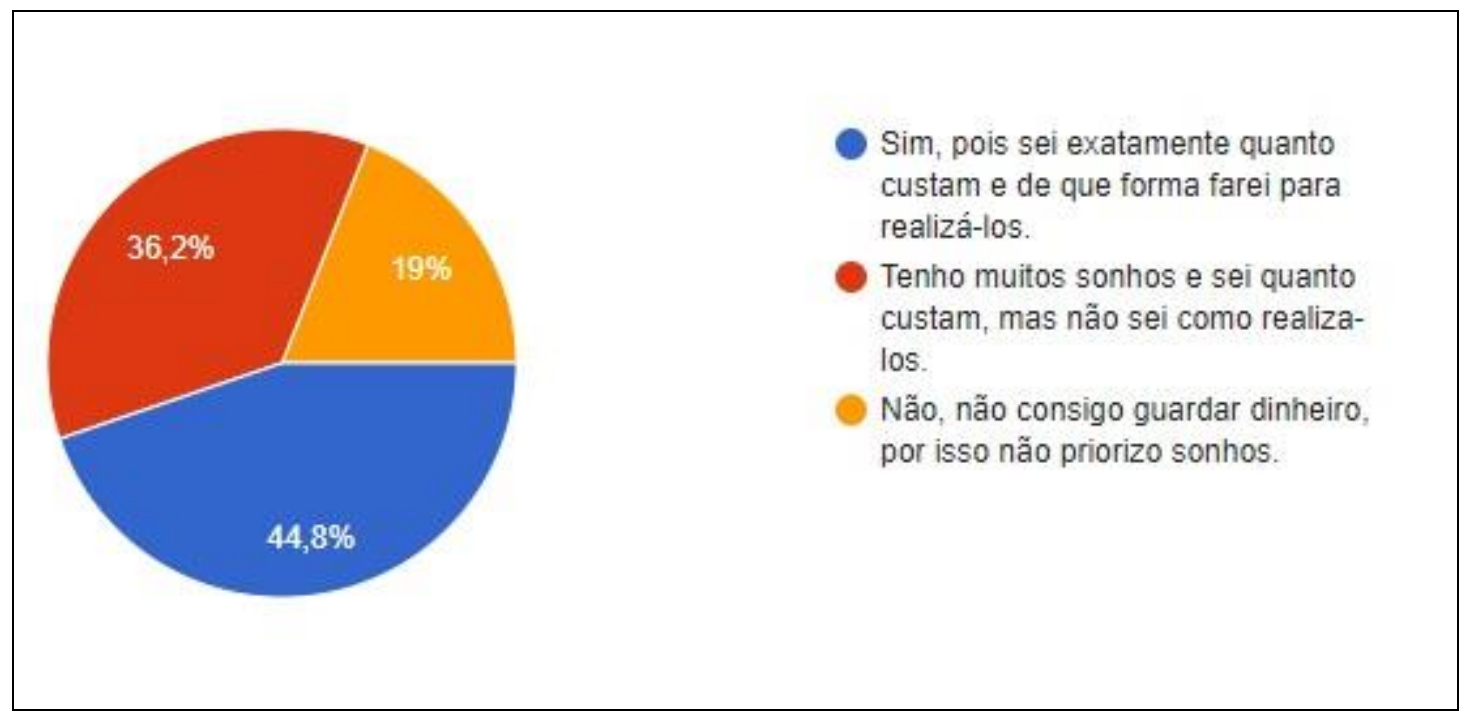

Gráfico 11 - Você sabe como irá realizar seus sonhos e desejos de curto prazo (até um ano) e longo prazo (até dez anos)?

Fonte: Própria.

Correlacionando as respostas obtidas acima, e no intuito de descobrir se os respondentes realmente sabem e entendem como e porque guardar dinheiro, obtemos os seguintes dados:

Tabela 7 - Comparativo Reserva x Realização de sonho

\begin{tabular}{|l|c|c|c|c|}
\cline { 2 - 5 } \multicolumn{1}{l|}{} & \multicolumn{3}{|c|}{$\begin{array}{c}\text { Você sabe como irá realizar seus sonhos e desejos } \\
\text { de curto prazo (até um ano) e longo prazo (até dez } \\
\text { anos)? }\end{array}$} \\
\hline $\begin{array}{l}\text { Você possuiu algum tipo de reserva? } \\
\text { Caso ocorra um imprevisto, qual seria } \\
\text { o impacto dele na sua vida financeira? }\end{array}$ & $\begin{array}{c}\text { Tenho muitos } \\
\text { sonhos e sei } \\
\text { quanto custam, } \\
\text { mas não sei como } \\
\text { realizá-los. }\end{array}$ & $\begin{array}{c}\text { Não, não consigo } \\
\text { guardar dinheiro, } \\
\text { por isso não } \\
\text { priorizo sonhos. }\end{array}$ & $\begin{array}{c}\text { Sim, pois sei } \\
\text { exatamente } \\
\text { quanto custam e } \\
\text { de que forma } \\
\text { farei para realizá- } \\
\text { los. }\end{array}$ \\
\hline $\begin{array}{l}\text { Sim. Estaria tranquilo pois } \\
\text { minha reserva equivale a seis } \\
\text { meses dos meus gastos } \\
\text { mensais. }\end{array}$ & 32 & 9 & 0 & 23 \\
\hline $\begin{array}{l}\text { Não. Ficaria perdido e não } \\
\text { saberia como começar a } \\
\text { resolver esses problemas. }\end{array}$ & 17 & 7 & 7 & 3 \\
\hline $\begin{array}{l}\text { Não, mas faria alguns cortes e } \\
\text { ajustes e me estabilizaria } \\
\text { novamente. }\end{array}$ & 57 & 22 & 14 & 21 \\
\hline \multicolumn{1}{|c|}{ Totais } & 106 & 38 & 21 & 47 \\
\hline
\end{tabular}

Fonte própria 
Nota-se então, que os 30,2\% que possuem uma reserva de emergência encontram-se alinhados em suas atitudes, isso porque, conseguem compreender a importância de possuir uma reserva e que isso colabora para a realização de metas futuras, pois todos eles possuem suas reservas e sabem exatamente como farão para realizar seus sonhos.

Outro fator importante é que 54\% (57 indivíduos) acreditam que conseguem realizar cortes e ajustarem suas dividas mediante imprevistos, mas dentro deste grupo $38,6 \%$ não sabem como realizar seus sonhos, assim, pode-se dizer que apesar de afirmarem que podem se estabilizar novamente e ajustarem seus gastos diante de uma dívida, eles não possuem uma perspectiva de planejamento para o futuro. Nota-se assim, que eles podem resolver o presente, mas não saber como se planejar para o futuro pode ser considerado incoerência de atitudes.

Diante desses dados, percebe-se então, que apesar do grupo estudado estar conseguindo arcar com suas despesas mensais, a grande maioria não consegue guardar dinheiro para sua independência financeira ou para imprevistos. Ou seja, o elevado número de pessoas que não realizam um planejamento ou que apenas fazem anotações $(58,5 \%)$ nos faz acreditar que, planejar as finanças de uma forma completa e periódica, não é um processo considerado importante para obter melhores resultados nas finanças desses indivíduos.

Ainda no bloco de planejamento e para uma maior análise de resultados, foram questionados sobre a movimentação de seu patrimônio e sobre o estilo de vida de cada um, e se era condizente com sua renda. Os resultados obtidos no gráfico 12 foram os seguintes: 


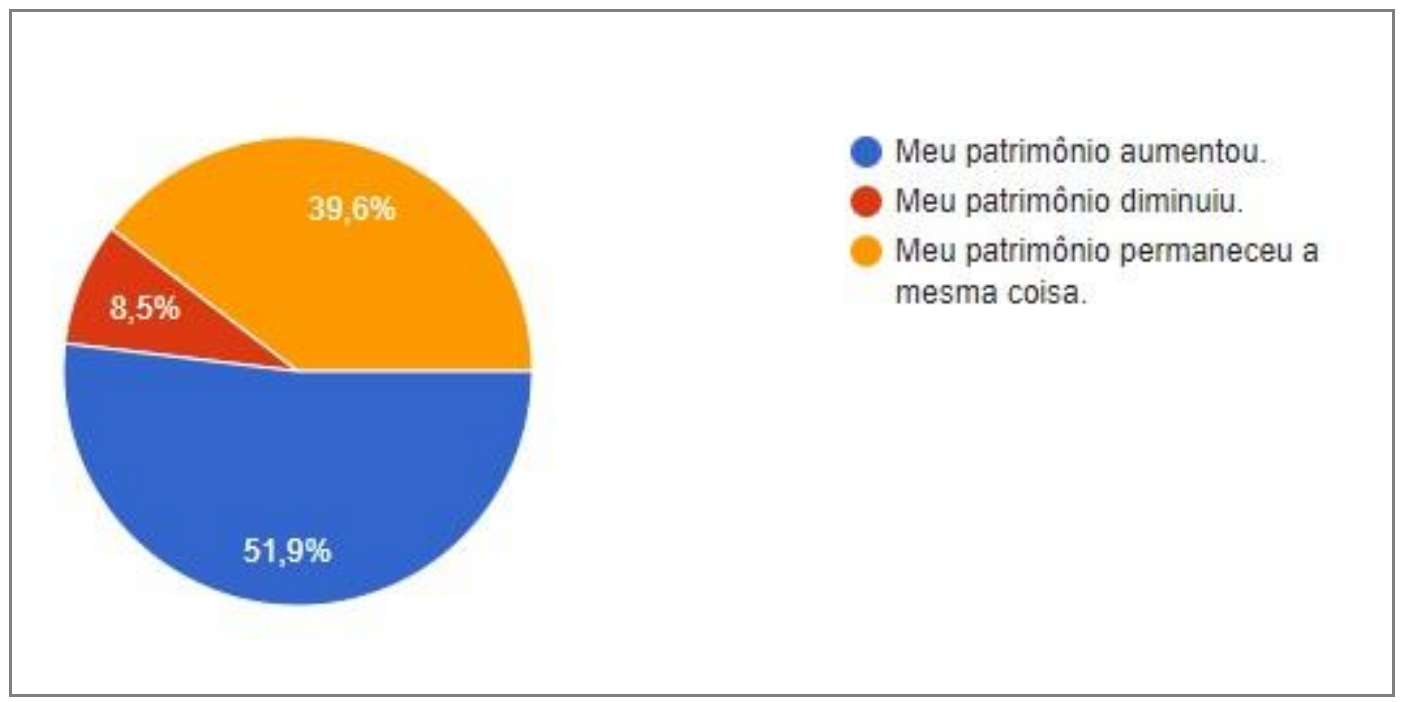

Gráfico 12 - Como você considera a movimentação do seu patrimônio nos últimos cinco anos?

Fonte própria

Mais da metade do grupo de pesquisa afirmou que seu patrimônio aumentou. Tal resultado, quando comparado a resposta obtida no gráfico 9, onde foram questionados sobre a pratica do planejamento orçamentário, são compatíveis. Isso porque, dos $51,9 \%$ que afirmam que obtiveram aumento de patrimônio, $41,5 \%$ praticam um planejamento orçamentário.

Tabela 8 - Comparativo Orçamento Mensal x Movimentação de Patrimônio

\begin{tabular}{|l|c|c|c|c|}
\cline { 3 - 5 } \multicolumn{2}{l|}{} & \multicolumn{2}{|c|}{$\begin{array}{c}\text { Como você considera a movimentação do seu } \\
\text { patrimônio nos últimos cinco anos? }\end{array}$} \\
\hline \multicolumn{2}{|c|}{ Você realiza algum orçamento mensal? } & $\begin{array}{c}\text { Meu patrimônio } \\
\text { aumentou }\end{array}$ & $\begin{array}{c}\text { Meu patrimônio } \\
\text { diminuiu }\end{array}$ & $\begin{array}{c}\text { Meu patrimônio } \\
\text { permaneceu a } \\
\text { mesma coisa }\end{array}$ \\
\hline $\begin{array}{l}\text { Apenas realizo anotações, mas não } \\
\text { faço nenhuma análise. }\end{array}$ & 42 & 22 & 4 & 16 \\
\hline $\begin{array}{l}\text { Pratico periodicamente um } \\
\text { planejamento e acompanhamento } \\
\text { necessário }\end{array}$ & 44 & 27 & 1 & 16 \\
\hline Não faço nenhum orçamento & 20 & 6 & 4 & 10 \\
\hline Totais & 106 & 55 & 9 & 42 \\
\hline
\end{tabular}

Fonte própria

Além disso, os $44,8 \%$, obtidos no gráfico 11 , que sabem exatamente como irão realizar seus sonhos, podem também explicar esse aumento no patrimônio pessoal, mesmo que não pratiquem o planejamento. 
Os participantes foram questionados sobre seu estilo de vida e se ele seria condizente com sua renda conforme demonstra o gráfico 13. A grande maioria, $54,7 \%$ responderam que em determinados momentos gastam mais do que deveriam, mas eles ainda acreditam que podem se ajustar. Esse percentual é compatível com o resultado obtido no gráfico 10 , pois os indivíduos creem que somente cortes e ajustes são capazes de resolver problemas. Mas o que eles não visualizam, é que a longo prazo, essa estratégia, pode ser arriscada e prejudicial para a sua saúde financeira.

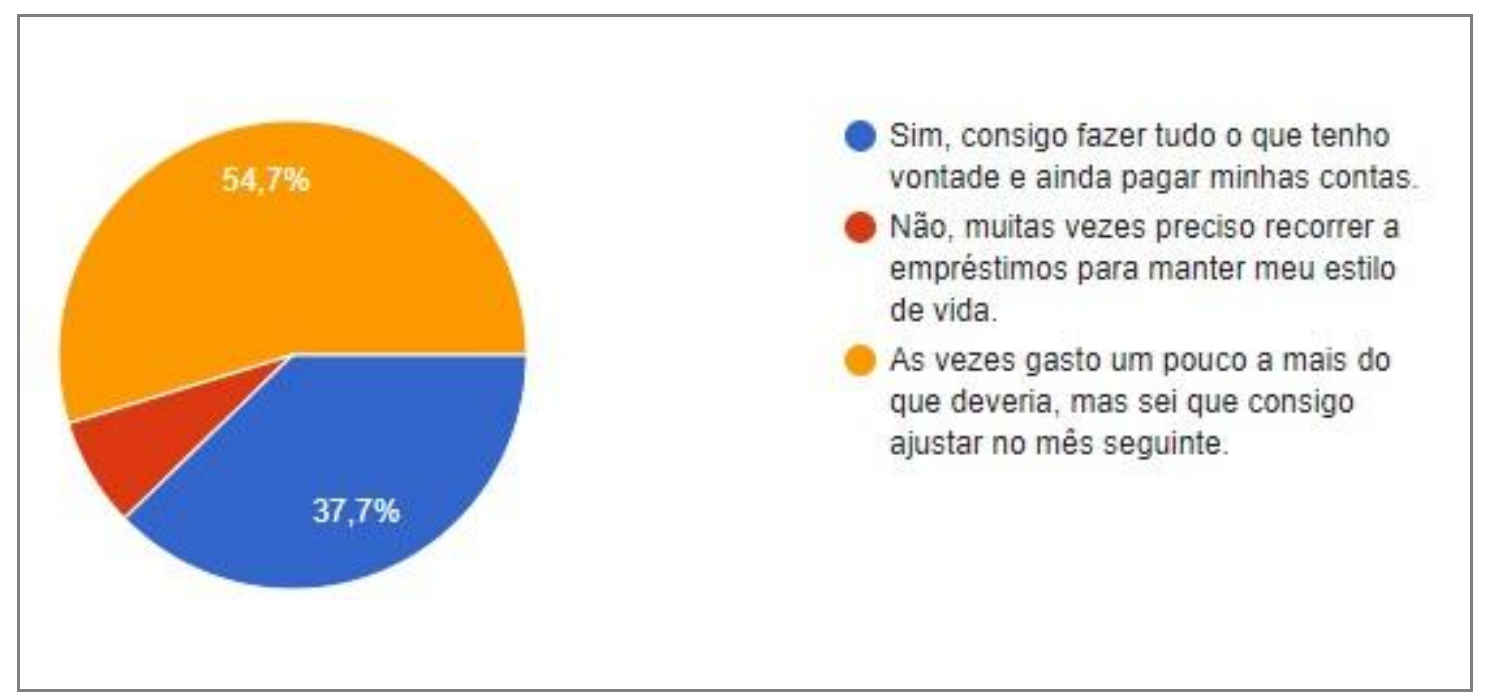

Gráfico 13 - Você acha que seu estilo de vida é condizente com a sua renda atual? Fonte Própria

\subsection{ENDIVIDAMENTO}

No gráfico 14 do terceiro bloco, buscou-se apurar sobre questões relacionadas ao endividamento. Questionados sobre qual afirmativa definiria a situação atual de endividamento, 48,1\% afirmam terem poucas ou nenhuma dívida atualmente, 37,7\% dizem que possuem certa quantidade de dívidas, mas que não enfrentam grandes problemas para pagá-las e 14,2\% afirmam possuírem dívidas e que podem (ou já tem) dificuldade em pagá-las. 


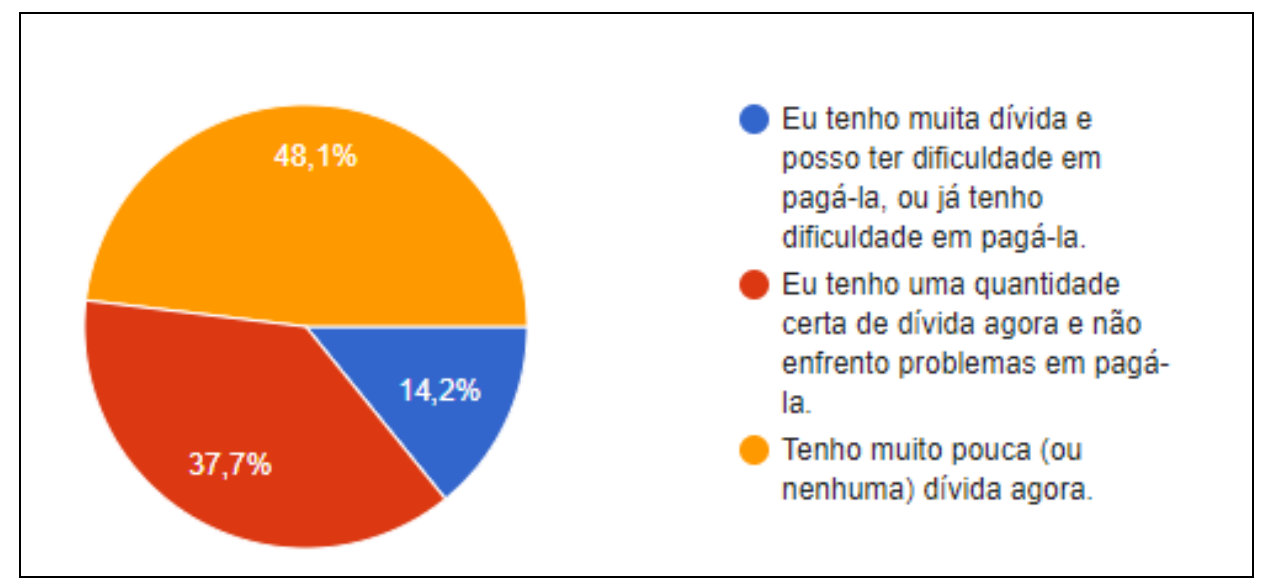

Gráfico 14 - Qual das seguintes afirmativas melhor descreve sua situação atual de endividamento? Consideramos endividamento ao conjunto de todos os seus compromissos financeiros.

Fonte Própria

No gráfico 15, Eles também foram questionados sobre o uso do cartão de crédito, visto que no relatório divulgado pela Confederação Nacional de Comércio de Bens, Serviços e Turismo em abril de 2019, revelou que o percentual de famílias que relataram estar endividadas foi de $62,7 \%$ e que segundo o relatório, o cartão de crédito foi indicado por $77,6 \%$ como o primeiro tipo de endividamento das famílias brasileiras.

Apesar disso, o resultado obtido na pesquisa foi positivo, visto que a maioria afirma que consegue fazer uso de cartão de crédito sem perder o controle como mostra o gráfico abaixo.

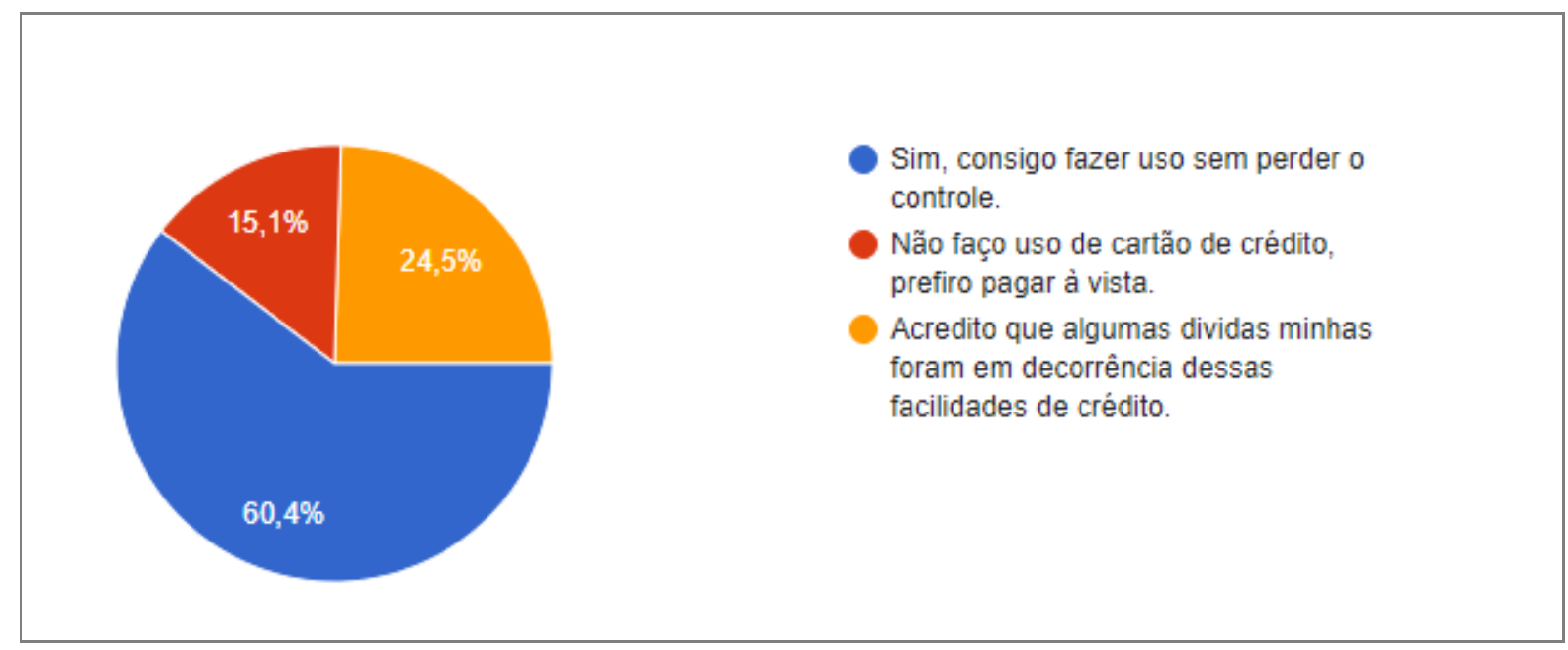

Gráfico 15 - Você se considera uma pessoa preparada para fazer uso de cartão de crédito sem perder o controle? Fonte própria 
O cartão de crédito foi considerado no relatório da CNC como o principal fator de endividamento dos brasileiros, seguido de carnês para $15,3 \%$ e por financiamento de automóvel por $10 \%$. E neste trabalho, a amostra também foi questionada sobre, se em algum momento já teriam feito uso de algum produto de crédito. Apenas $34 \%$ afirmam que nunca utilizaram de produto de crédito disponível no mercado, 6,6\% afirmou utilizar do dinheiro disponível que o cartão de crédito oferece e apenas $0,9 \%$ afirmaram utilizar do limite de crédito disponível em conta corrente.

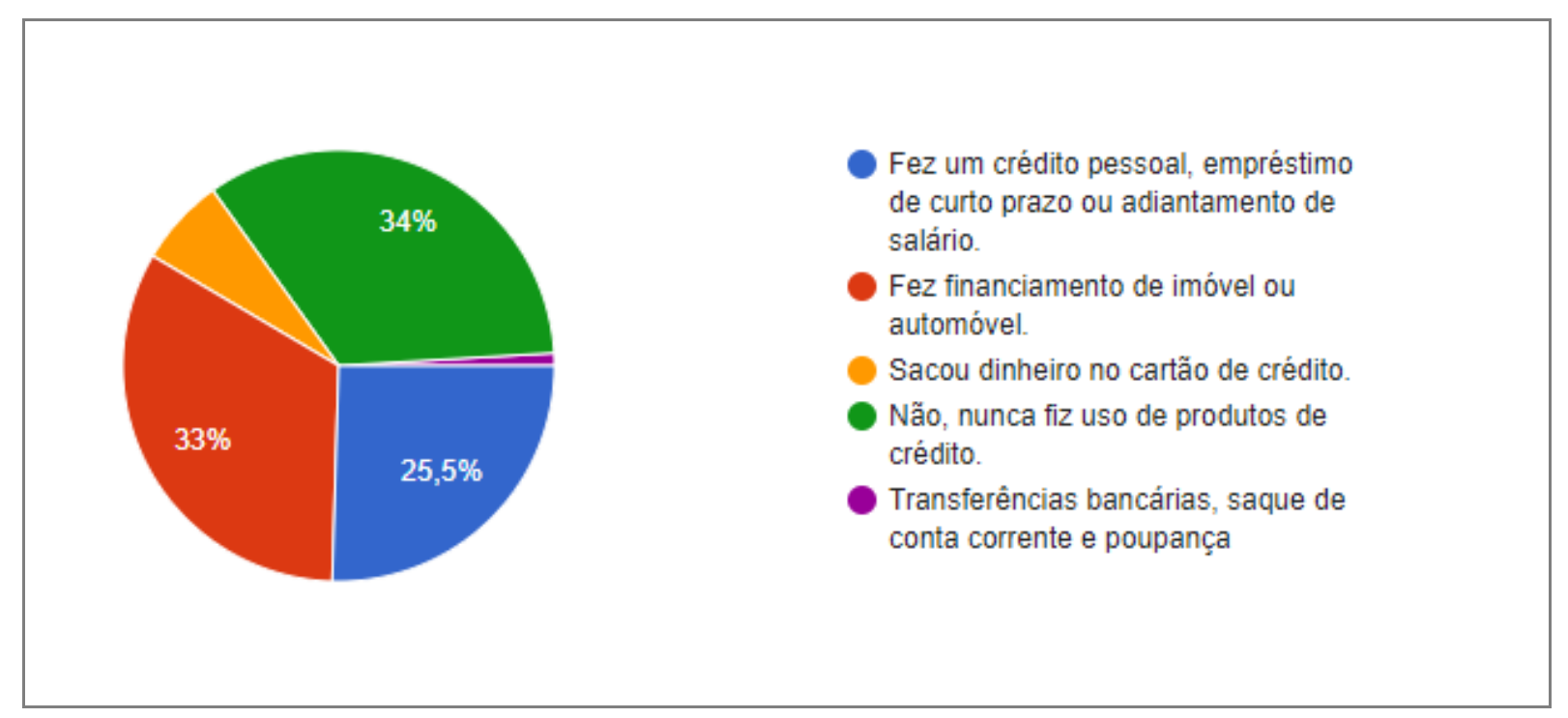

Gráfico 16 - Você alguma vez...

Fonte própria

Nota-se assim, que apesar dos $43,8 \%$ que arcam com suas dívidas e poupam e dos $47,6 \%$ que honram com suas dívidas mensais, mas que não conseguem fazer com que sobre dinheiro - como foi possível observar no gráfico 8 muitos já precisaram ou ainda precisam recorrer a outros meios para aumentar sua renda mensal, e assim arcar com seus compromissos e manterem seus padrões de vida. 


\subsection{INVESTIMENTO}

Com a finalidade de identificar como a amostra não somente procura investir, mas como também planeja seu futuro, a quarta seção abordou questões desse aspecto.

Como visto no gráfico 17, quando questionados acerca de sua atitude em poupança e investimento nos últimos doze meses, 39,6\% afirmam que em alguns meses conseguiram poupar e investir; 37,2\% afirmam que não conseguiram economizar nada e $22,6 \%$ afirma que conseguiram poupar e investir em todos os meses.

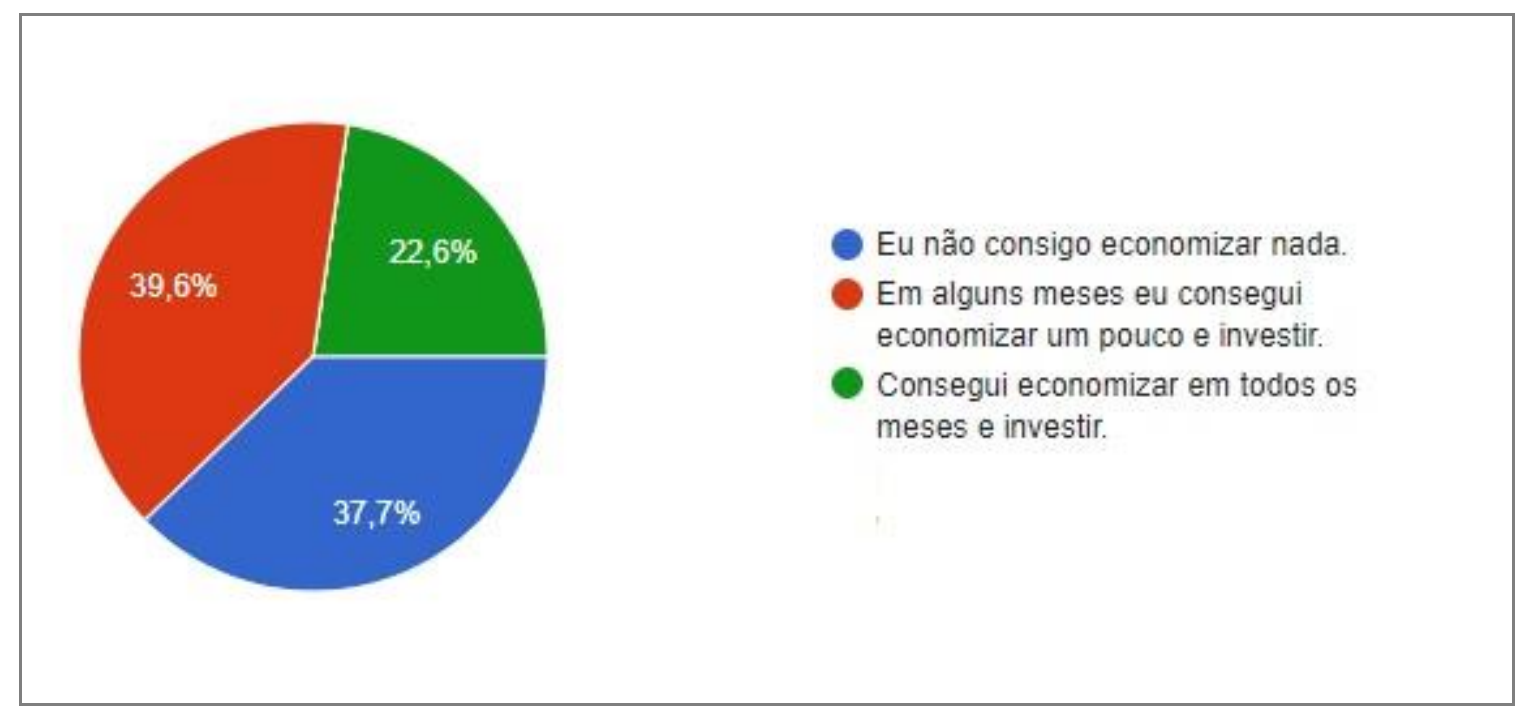

Gráfico 17 - Nos últimos doze meses, qual destas afirmativas descreve sua atitude de poupança/investimento?

Fonte Própria

No gráfico 18, eles também foram questionados acerca da sua posição atual de investimentos. Somente 4,8\% afirmam terem investimentos diversificados e estarem preparados para o futuro; a grande maioria $(70,5 \%)$ possui pouco ou nenhum investimento. 


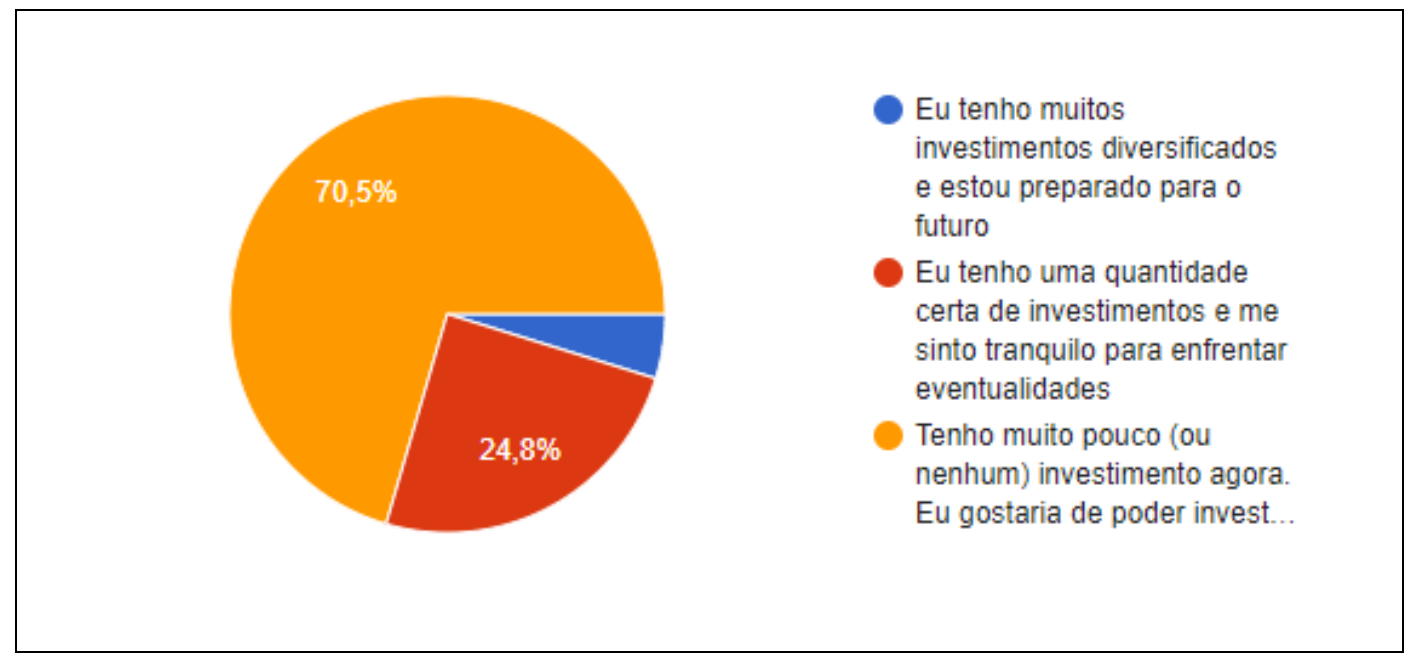

Gráfico 18 - Qual das seguintes afirmativas melhor descreve sua posição atual de investimento?

Fonte Própria

Quando cruzamos as informações fornecidas, percebemos que mesmo aqueles que não conseguiram economizar nos últimos meses ainda se sentem tranqüilos com a quantidade atual de investimentos, isso pode ser em decorrência de economias em anos anteriores.

Nota-se também que mesmo aqueles que conseguiram economizar em todos os meses, ainda não se sentem satisfeitos, pois possuem poucos investimentos, mas a maioria, cerca de $54,2 \%$ (13 respondentes) considera que seus investimentos são adequados e se sentem seguros quanto a eles, como é possível visualizar na tabela 9.

Tabela 9 - Comparativo Atitudes de Investimentos x Posição atual de investimento

\begin{tabular}{|c|c|c|c|c|}
\hline & & \multicolumn{3}{|c|}{$\begin{array}{c}\text { Qual das seguintes afirmativas melhor descreve sua } \\
\text { posição atual de investimento? }\end{array}$} \\
\hline \multicolumn{2}{|c|}{$\begin{array}{c}\text { Nos últimos doze meses, qual } \\
\text { destas afirmativas descreve sua } \\
\text { atitude de } \\
\text { poupança/investimento? }\end{array}$} & $\begin{array}{l}\text { Eu tenho uma } \\
\text { quantidade certa de } \\
\text { investimentos e me } \\
\text { sinto tranquilo para } \\
\text { enfrentar }\end{array}$ & $\begin{array}{l}\text { Tenho muito pouco } \\
\text { (ou nenhum) } \\
\text { investimento agora. } \\
\text { Eu gostaria de } \\
\text { poder investir mais. }\end{array}$ & $\begin{array}{c}\text { Eu tenho muitos } \\
\text { investimentos } \\
\text { diversificados e } \\
\text { estou preparado } \\
\text { para o futuro }\end{array}$ \\
\hline $\begin{array}{l}\text { Em alguns meses eu } \\
\text { consegui economizar um } \\
\text { pouco e investir. }\end{array}$ & 42 & 11 & 30 & 1 \\
\hline $\begin{array}{l}\text { Eu não consegui } \\
\text { economizar nada }\end{array}$ & 40 & 2 & 38 & 0 \\
\hline $\begin{array}{l}\text { Consegui economizar em } \\
\text { todos os meses e investir. }\end{array}$ & 24 & 13 & 7 & 4 \\
\hline Totais & 106 & 26 & 75 & 5 \\
\hline
\end{tabular}

Fonte Própria 
Para uma melhor avaliação dos investimentos para o grupo de amostra, foram questionados sobre qual seria a melhor opção de investimento para eles, e os dados obtidos estão sendo fornecidos na tabela 10.

Tabela 10 - Opções de Investimento

\begin{tabular}{|c|c|c|}
\cline { 2 - 3 } \multicolumn{1}{c|}{} & Frequência & Porcentagem \\
\hline Previdência Privada & 4 & $3,8 \%$ \\
\hline Títulos privados & 4 & $3,8 \%$ \\
\hline Títulos públicos & 16 & $15,1 \%$ \\
\hline Poupança & 23 & $21,7 \%$ \\
\hline Fundos de Investimentos & 23 & $21,7 \%$ \\
\hline Bens Materiais & 22 & $20,8 \%$ \\
\hline Não sei & 2 & $1,9 \%$ \\
\hline Outros & 12 & $11,3 \%$ \\
\hline Totais & $\mathbf{1 0 6}$ & $\mathbf{1 0 0} \%$ \\
\hline
\end{tabular}

Fonte Própria

Como é possível identificar na tabela 10, a poupança e os fundos de investimentos aparecem como os preferidos entre a amostra e representa $21,7 \%$ cada um. Em seguida com $20,8 \%$, os bens materiais, como imóveis e carros.

Esse resultado reforça a ideia já apontada no capítulo dois através do relatório Raio X do investidor divulgado pela Anbima no ano de 2018, onde foi apontado que a caderneta de poupança ainda é um dos produtos de investimentos preferido dos brasileiros. Reforça também o pensamento que para o brasileiro, aquilo que já é conhecido é o mais seguro, assim como aquilo que é tangível.

É possível chegar a esse resultado, pois durante a pesquisa deste trabalho, foram questionados sobre o que mais causa incerteza na hora de realizar um investimento. O resultado obtido está no gráfico 19. 


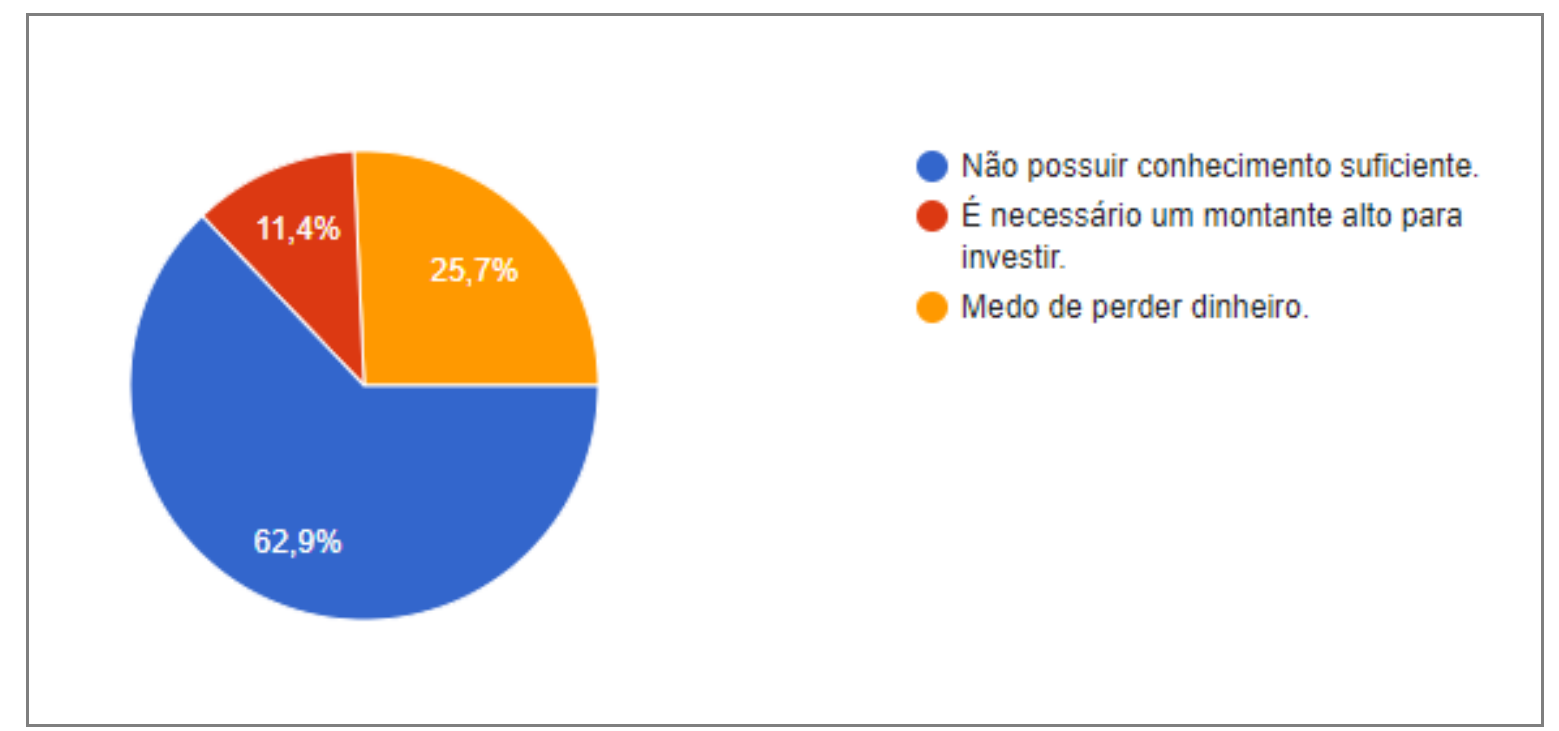

Gráfico 19 - Na sua opinião, o que mais causa incerteza na hora de realizar um investimento? Fonte Própria

Por último, foram questionados sobre frase definiria melhor sua opinião sobre o assunto. O resultado no gráfico 20 , mais uma vez, reafirma o resultado obtido pela Anbima, que segurança financeira é o fator motivacional dos brasileiros para poupar e investir.

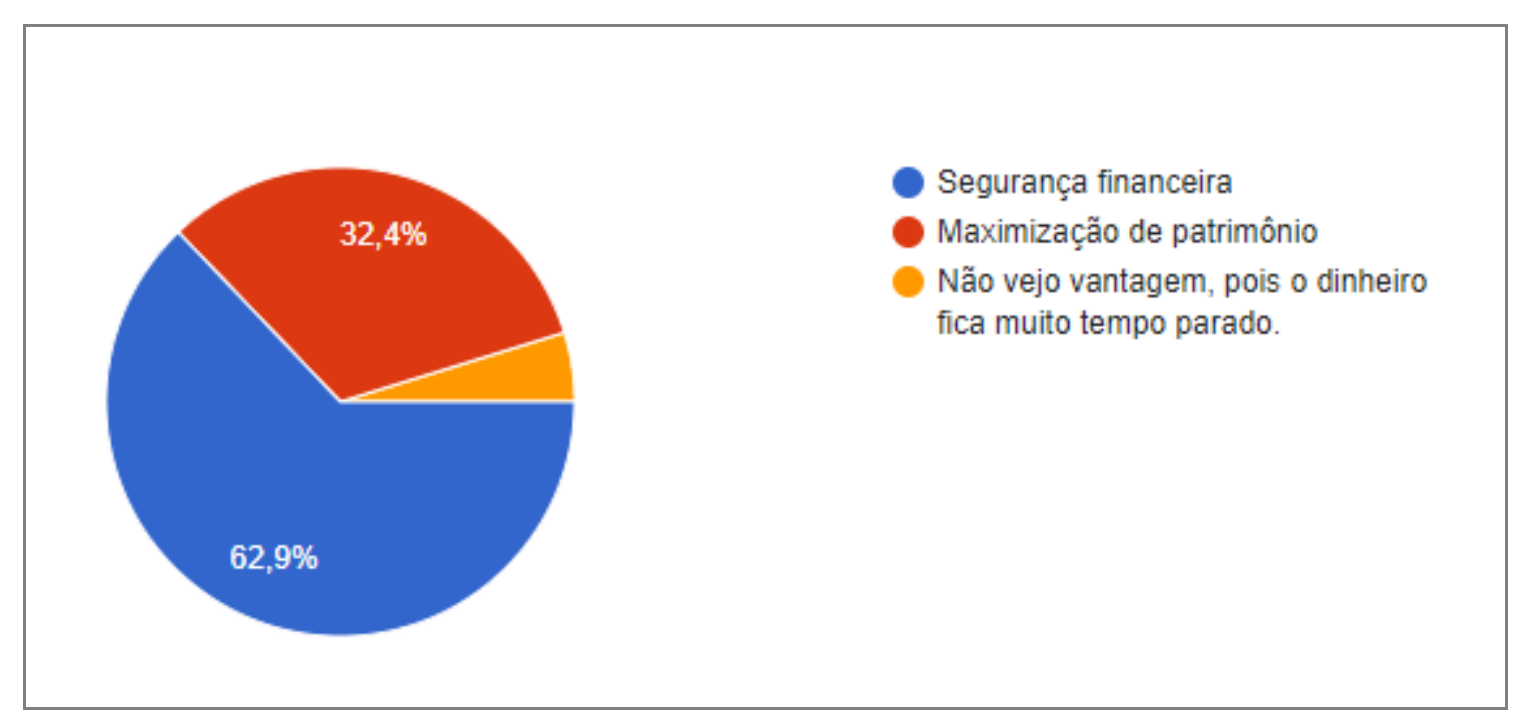

Gráfico 20 - Ainda que você não seja um investidor, que frase define melhor sua opinião quanto ao assunto?

Fonte própria

\subsection{CONHECIMENTO FINANCEIRO}

$\mathrm{Na}$ última seção, procurou responder e entender como, se e porque eles buscam conhecimento no assunto. Assim, foram questionados se nos últimos seis 
meses eles buscaram informações e qual seria o melhor modo de realizar essa busca.

Conforme o gráfico 21, mais da metade da amostra afirmou que buscaram obter mais conhecimento no assunto.

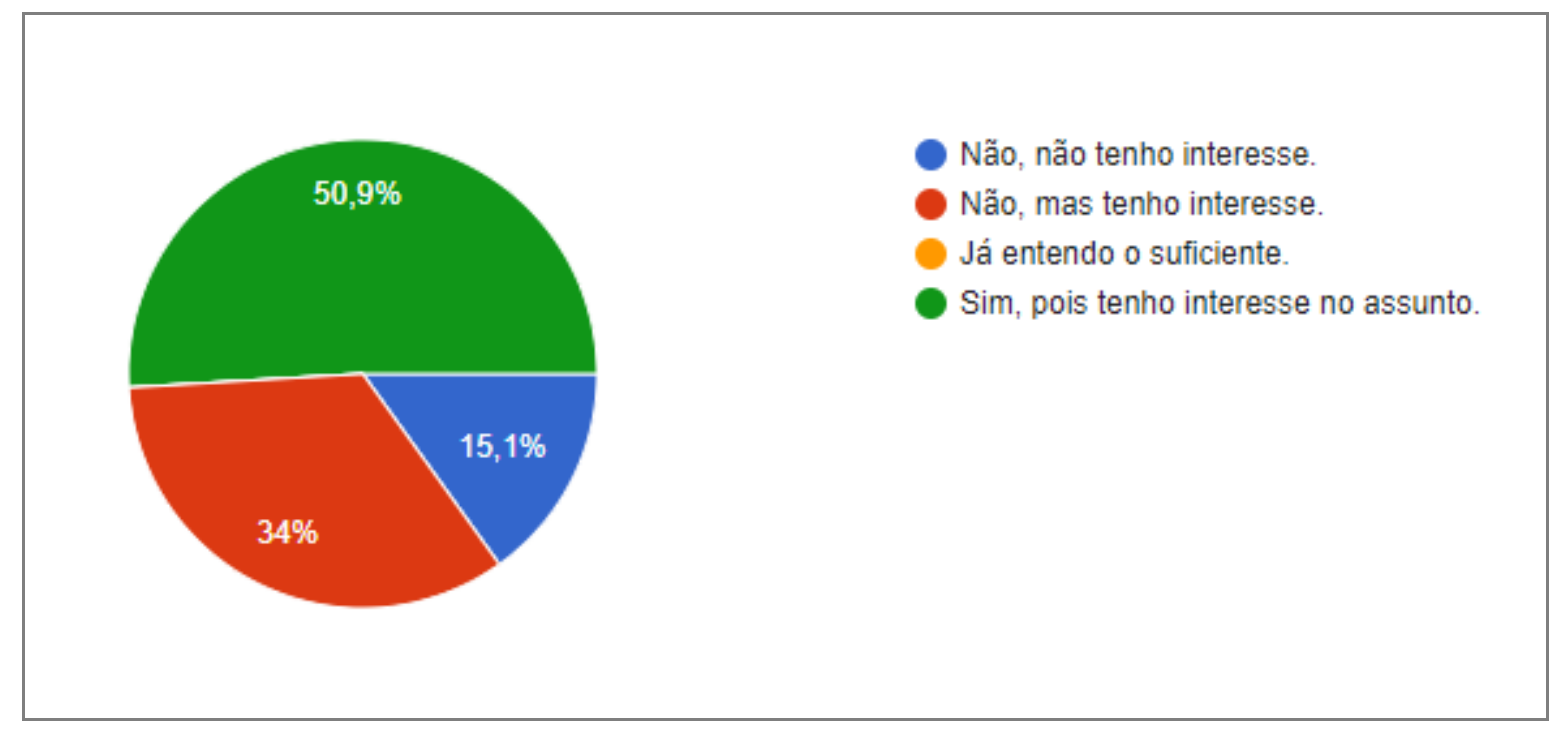

Gráfico 21 - Nos últimos seis meses, você buscou se informar sobre finanças? Fonte própria

Ainda assim, no gráfico 22, nota-se que a maioria (41\%) busca conhecimento com amigos e familiares, e que talvez não sejam pessoas especializadas ou com o conhecimento suficiente para que possa ser de total confiança. Pois como vimos nos resultados acima (gráfico 20), grande parte do grupo estudado prefere não se arriscar muito acreditando que aquilo que lhe dá mais segurança é a melhor opção para juntar dinheiro, seja para reservas, seja para o cumprimento de metas ou aumento de patrimônio. Isso é uma barreira criada pelos indivíduos, que não se permite arriscar mais para buscar outros meios de gerar mais renda. 


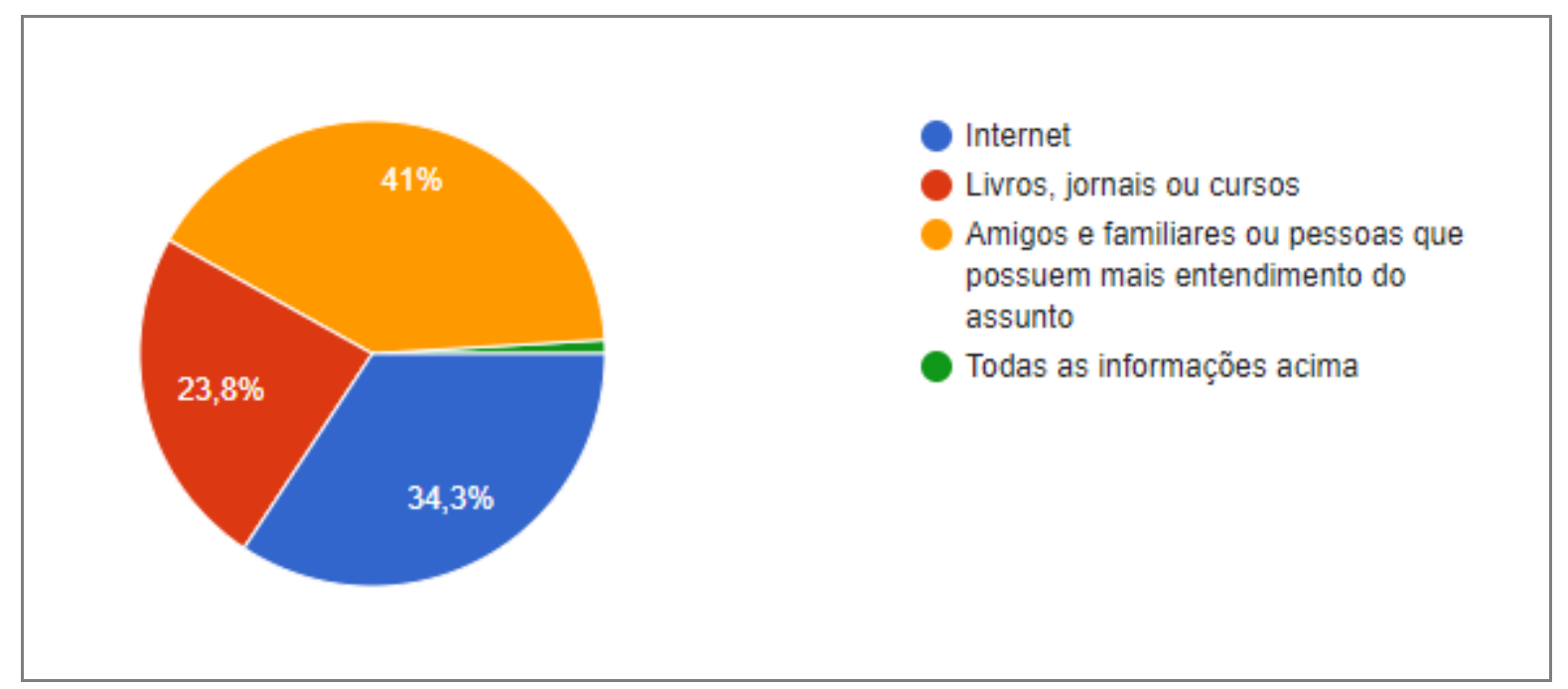

Gráfico 22 - Na sua opinião, qual o melhor meio de se informar sobre finanças? Fonte Própria

Por último, como mostra $\circ$ gráfico 23 , eles foram perguntados qual era 0 principal motivo que em sua opinião favorecia a elaboração de um planejamento financeiro. Apenas 0,9\% responderam não ver um motivo favorável para isso e $50,9 \%$ acreditam que um planejamento é capaz de auxiliar para que se possa alcançar objetivos.

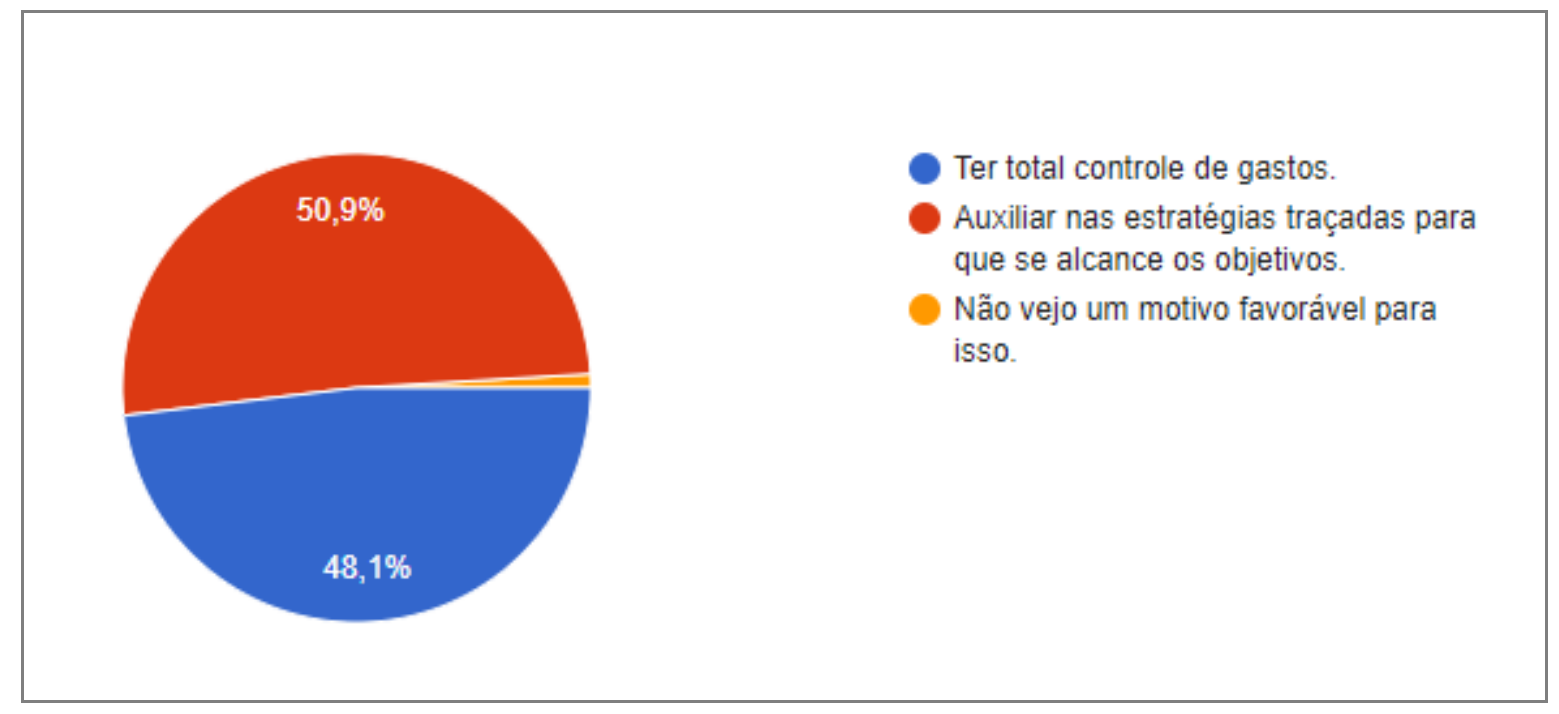

Gráfico 23 - Ainda que você não costume realizar nenhum tipo de planejamento, na sua opinião, qual o principal motivo que favorece a elaboração de um planejamento financeiro?

Fonte Própria 


\section{5- CONSIDERAÇÕES FINAIS}

O presente trabalho teve por objetivo avaliar o nível de conhecimento financeiro de um grupo de pessoas economicamente ativas, especialmente no que envolve o planejamento financeiro e também a aplicação prática realizada por eles em suas finanças pessoais. Para tal, foi realizada a pesquisa com intuito de analisar o conhecimento que os mesmos possuem de suas finanças e de um planejamento orçamentário pessoal, averiguando também o grau de endividamento e investimentos.

Diante disso e dos resultados, conclui-se que a temática financeira deveria ser mais presente nas conversas diárias, e assim mais disseminadas na sociedade, pois se trata de algo importante e fundamental na vida dos indivíduos, isso porque, saber lidar com o dinheiro é imprescindível.

Conclui-se que o conhecimento financeiro permite a realização de um bom planejamento financeiro, para que esse possa ser capaz de auxiliar nas conquistas pessoais dos indivíduos. Assim, esse planejamento deverá ser coerente com suas finanças e com seus desejos e metas, seguido de um bom plano de investimentos para que esse que possa ser aplicado de modo eficaz, e assim aumentar seu renda e seus ganhos.

Os resultados obtidos na etapa exploratória desse trabalho mostram alguns resultados que demandam atenção. Isso porque, 47,6\% do grupo de amostra, apesar de conseguirem arcar com suas despesas mensais, não conseguem fazer sobrar mais nada ao final do mês. Tal resultado, como foi apresentado na tabela 6 , nos faz crer que esse número elevado seja resultado da falta de planejamento dos mesmos, isso porque, somente $41,5 \%$ possuem o costume de realizar um planejamento orçamentário e acompanhar com regularidade o essa planejamento. Ou seja, o elevado número de pessoas que não realizam um planejamento ou que apenas fazem anotações (58,5\%) nos faz acreditar que, planejar as finanças de uma forma completa e periódica, não é um processo considerado importante para obter melhores resultados nas finanças desses indivíduos.

Outro fato observado e que enfatiza esse resultado, é que mais da metade não possuem uma reserva de emergência para cobrir eventuais problemas, muitos acreditam que podem voltar a se estabilizar apenas realizando cortes e ajustes. 
Nas questões que tangem 0 endividamento do grupo pesquisado, 0 resultado foi condizente com os resultados obtidos no bloco de planejamento. Isso porque, $48,1 \%$ afirmam não terem dívidas. Esse resultado aponta um alinhamento entre os respondentes dessa pesquisa, visto que $51,9 \%$ afirmam que conseguiram aumentar seu patrimônio, onde foram considerados os últimos cinco anos.

Em relação a investimentos, assim como foi citado no referencial teórico deste trabalho, o grupo pesquisado mostrou-se também resistente a possíveis riscos. Isso porque uma quantidade considerável ainda é adepta de investimentos tradicionais e conversadores, como a caderneta da poupança e uma outra quantidade de bens materiais. Essa aversão a maiores riscos, foi avaliada por eles e a maioria acredita que não possuir o conhecimento suficiente, é o que os impede de não investirem mais ou buscar outras opções de investimento. Diante desses dados, conclui-se então que o grupo pesquisado segue uma linha mais conservadora, mas mesmo que ainda não se sintam capazes de sair dessa zona, a grande maioria também respondeu que continuou buscando mais informações sobre finanças nos últimos seis meses.

Sendo assim, conclui-se o grupo pesquisado, possui um entendimento sobre planejamento financeiro e compreende sua necessidade, já que quase a sua totalidade acredita que o planejamento é um bom modo de controlar os gastos e também serve como um bom auxiliador de estratégias.

Por fim, temas podem ser levantados como implicação para pesquisas futuras: a realização de pesquisa para grupos onde as amostras tenham dívidas ou não, a fim de testar como esses grupos encaram a necessidade de um planejamento financeiro. 


\section{REFERÊNCIAS:}

ANBIMA. Pesquisa. Raio $\mathbf{X}$ do investido. Disponível em: $<$ http://www.anbima.com.br/pt_br/especial/raio-x-do-investidor-2019.htm > Acesso em: 02 abr. 2019.

ANBIMA. Pesquisa. Relação dos brasileiros com o dinheiro. Disponível em: <http://www.anbima.com.br/pt_br/especial/relacao-do-brasileiro-com-o-dinheiro.htm> Acesso em: 30 mar. 2019.

ARAUJO, Fabio de Almeida Lopes; SOUZA, Marcos Aguerri Pimenta de. Educação Financeira para um Brasil Sustentável, Working Papers Series 280, Banco Central do Brasil. Brasil, Departamento de Pesquisa. 2012. Disponível em:

https://ideas.repec.org/p/bcb/wpaper/280.html. Acesso em: 01 Mai. 2019.

ASSAF NETO, A. Mercado financeiro. 8. ed. São Paulo: Atlas, 2008.

BARRATO, George; BELINKY, Aron; Helio. O Consumo consciente do dinheiro e do crédito. Caderno Temático, 2006. Disponível em

http://www.akatu.org.br/Content/Akatu/Arquivos/file/ Caderno Temático Dinheiro Credito.pdf. Acesso em: 2 Mai. 2019.

BOVESPA. Histórico pessoas físicas. Ago. 2018 Disponível em:

<http://www.bmfbovespa.com.br/pt_br/servicos/market-data/consultas/historicopessoas-fisicas/>. Acesso em: 07 out. 2018.

BRASIL. Estratégia Nacional de Educação Financeira. ENEF. Decreto 7.397 de 22 dezembro de 2010. Disponível em:

$<$ http://www.vidaedinheiro.gov.br/quemsomos>. Acessado em 30 de novembro de 2018

BRASIL. População Brasileira ultrapassa 208 milhões. Disponível em:

$<$ http://www.brasil.gov.br/noticias/cidadania-e-inclusao/2018/08/populacao-brasileiraultrapassa-208-milhoes-de-pessoas-revela-ibge>. Acesso em: 07 out. 2018.

BRASIL. Porque a econômica brasileira foi pro buraco. Disponível em:<http://www.brasil-economia-governo.org.br/2015/08/25/por-que-a-economiabrasileira-foi-para-o-buraco/)> Acesso em: 07 out. 2018.

CERBASI, G. Casais inteligentes enriquecem juntos. Rio de Janeiro: Sextante. 2014

CERBASI, G. Como organizar sua vida financeira. Rio de Janeiro: Sextante. 2015

CHEROBIM, A. P. M. S.; ESPEJO, M. M. dos S. B. (Org.) Finanças Pessoais:

Conhecer para enriquecer. São Paulo: Atlas, 2010.

CONFEDERAÇÃO NACIONAL DO COMÉRCIO DE BENS, SERVIÇOS E TURISMO. Percentual de famílias com dívidas fica estável em setembro de 2018. Disponível em:

<http://cnc.org.br/sites/default/files/arquivos/analise_peic_setembro_2018_0.pdf > . Acesso em: 07 out. 2018. 
CONFEDERAÇÃO NACIONAL DO COMÉRCIO DE BENS, SERVIÇOS E TURISMO. Peic-Abril 2019. Disponível em:

$<$ http://cnc.org.br/editorias/economia/pesquisas/peic-abril-de-2019 > Acesso em: 25 abr. 2019.

FRANKENBERG, L. Seu futuro financeiro. 16.ed. Rio de Janeiro: Campus, 1999

GIL, A. C. Métodos e técnicas de pesquisa social. 5.ed. São Paulo: Atlas, 1999.

GITMAN, L. J. Princípios da administração financeira. 10.ed. São Paulo: Pearson Adilson Wesley, 2001.

GRAEMAUD, Amaury Patrick. Economia Brasileira Contemporânea. São Paulo: Editora Atlas. Sexta edição. 2007

HALFED, M. Investimentos: como administrar melhor seu dinheiro. São Paulo: Fundamento Educacional, 2006.

IBGE (Instituto Brasileiro de Geografia e Estatística). Notas Metodológicas.

Disponível em:

<https://ww2.ibge.gov.br/home/estatistica/indicadores/trabalhoerendimento/pme/pme met2.shtm>. Acesso em: 04 jul. 2019.

MEC (Ministério da Educação). Parâmetros curriculares nacionais: ensino médio. 2000a. Disponível em <http://portal.mec.gov.br/seb/arquivos/pdf/blegais.pdf> acesso em: 30 nov. 2018.

OCDE (Organização de Cooperação e de Desenvolvimento Econômico). OECD's Financial Education Project. Assessoria de Comunicação Social, 2004. Disponível em: <www.oecd.org/> acessado em 21 de outubro de 2018.

OLIVEIRA, Djalma de Pinho Rebouças. Planejamento Estratégico. 26ª ed. São Paulo. Atlas. 2009.

PEREIRA, Ana Maria. Informação, Globalização e educação: desafios de uma nova era. Portal de Periódicos Científicos da UEL. 2001. Disponível em: $<$ www.uel.br/revistas/uel/index.php/informacao/article/download/1688/1439. . . Acesso em: 07 out. 2018.

PLACEDINO, Márcio. Educação financeira. 2009. Disponível em: <http://educarfinancas.com.br/ author/marcioplacedino/> Acesso em: 16 Mai. 2019.

SAITO, A. T. Uma Contribuição ao Desenvolvimento da Educação em Finanças Pessoais no Brasil. Dissertação (Mestrado em Administração) - Faculdade de Economia, Administração e Contabilidade, Universidade de São Paulo. 2007. São Paulo.

SAVOIA, J.R.F.; SAITO, A. T.; SANTANA, F.A.; Paradigmas da educação financeira no Brasil - Revista de Administração Pública, Artigo. 2007

SERASA EXPERIAN. Educação financeira do brasileiro vai além da escolaridade, revela estudo inédito da Serasa Experian e do IBOPE Inteligência. São Paulo. 2019. Disponível em: 
<https://www.serasaexperian.com.br/sala-de-imprensa/educacao-financeira-dobrasileiro-vai-alem-da-escolaridade-revela-estudo-inedito-da-serasa-experian-e-doibope-inteligencia> Acesso em: 26 mar. 2019

TESOURO NACIONAL. Tesouro Direito tem recorde de investidores cadastrados em junho. Disponível em: <http://www.tesouro.fazenda.gov.br//tesouro-direto-tem-recorde-de-investidores-cadastrados-em-junho> Acesso em: 07 out. 2018.

TOLOTTI, Márcia. As armadilhas do consumo: acabe com o endividamento. Rio de Janeiro: Elsevier, 2007. 


\section{ANEXO 1}

\section{Pesquisa em finanças pessoais}

O objetivo desta pesquisa é identificar a relação das pessoas com o conhecimento das suas finanças pessoais, assim irá nos permitir conhecermos mais sobre como as pessoas lidam com o dinheiro.

Sua colaboração é muito nesta pesquisa. Ela é muito importante para este trabalho acadêmico.

\section{Sobre você}

Primeiramente precisamos conhecer um pouco sobre você.

A seguir, você tem algumas perguntas que ajudarão na análise dos dados.

1. Primeiramente, gostaríamos de saber sua faixa etária.

Marcar apenas uma oval.
Até 21 anos
De 22 a 39 anos
De 40 a 52 anos
De 53 a 72 anos

2. Em qual região do país você reside atualmente ? Marcar apenas uma oval.
$\longrightarrow$ Norte
Nordeste
Centro-oeste
Sul
Sudeste

3. Qual seu nível de escolaridade? Marcar apenas uma oval.
Ensino fundamental incompleto
Ensino fundamental completo
Ensino médio incompleto
Ensino médio completo
Ensino superior incompleto
Ensino superior completo

4. Sua renda se aproxima de qual opção abaixo ?

Marcar apenas uma oval.
Até 3 salários minimos
De 3 a 6 salários
Mais de 6 salários 
07/06/2019

Pesquisa em finanças pessoais

5. Incluindo todas as suas fontes de renda, você se sente com seus ganhos?

Marcar apenas uma oval.

Satisfeito

Nem satisfeito, nem insatisfeito

Insatisfeito

\section{Planejamento Financeiro}

Nesta seção apesentamos perguntas para responder como você costuma se organizar financeiramente e saber se você sabe cuidar do seu dinheiro.

6. Você realiza algum orçamento mensal ?

Marcar apenas uma oval.

Não faço nenhum orçamento.

Apenas realizo anotações, mas não faço nenhuma análise.

Pratico periodicamente um planejamento e o acompanhamento necessario.

7. A sua renda mensal é suficiente para arcar com todas as despesas do mês? Marcar apenas uma oval.

Sim, mas não sobra nada.

Não, e ainda preciso pedir emprestado a amigos e parentes ou instituições financeiras.

Sim, consigo pagar as contas e ainda consigo poupar.

8. Você possuiu algum tipo de reserva? Caso ocorra um imprevisto, qual seria o impacto dele na sua vida financeira?

Marcar apenas uma oval.

Sim.Estaria tranquilo pois minha reserva equivale a seis meses dos meus gastos mensais.

Não.Ficaria perdido e não saberia como começar a resolver esses problemas.

Não, mas faria alguns cortes e ajustes e me estabilizaria novamente.

9. Você sabe como irá realizar seus sonhos e desejos de curto prazo (até um ano) e longo prazo (até dez anos) ?

Marcar apenas uma oval.

Sim, pois sei exatamente quanto custam e de que forma farei para realizá-los.

Tenho muitos sonhos e sei quanto custam, mas não sei como realiza-los.

Não, não consigo guardar dinheiro, por isso não priorizo sonhos.

10. Como você considera a movimentação do seu patrimônio nos últimos cinco anos ? Marcar apenas uma oval.

Meu patrimônio aumentou.

Meu patrimônio diminuiu.

Meu patrimônio permaneceu a mesma coisa. 
07/06/2019

Pesquisa em finanças pessoais

11. Você acha que seu estilo de vida é condizente com a sua renda atual ?

Marcar apenas uma oval.

Sim, consigo fazer tudo o que tenho vontade e ainda pagar minhas contas.

Não, muitas vezes preciso recorrer a empréstimos para manter meu estilo de vida.

As vezes gasto um pouco a mais do que deveria, mas sei que consigo ajustar no mês seguinte.

\section{Endividamento}

Esta seção é destinada a perguntas sobre decisões de crédito e endividamento.

12. Qual das seguintes afirmativas melhor descreve sua situação atual de endividamento? Consideramos endividamento ao conjunto de todos os seus compromissos financeiros.

Marcar apenas uma oval.

Eu tenho muita dívida e posso ter dificuldade em pagá-la, ou já tenho dificuldade em pagá-la.

Eu tenho uma quantidade certa de dívida agora e não enfrento problemas em pagá-la.

Tenho muito pouca (ou nenhuma) dívida agora.

13. Você se considera uma pessoa preparada para fazer uso de cartão de crédito sem perder o controle?

Marcar apenas uma oval

Sim, consigo fazer uso sem perder o controle.

Não faço uso de cartão de crédito, prefiro pagar à vista.

Acredito que algumas dividas minhas foram em decorrência dessas facilidades de crédito

14. Você alguma vez...

Marcar apenas uma oval.

Fez um crédito pessoal, empréstimo de curto prazo ou adiantamento de salário.

Fez financiamento de imóvel ou automóvel.

Sacou dinheiro no cartão de crédito.

Não, nunca fiz uso de produtos de crédito.

Outro:

\section{Investimento}

Esta seção é destinada a perguntas sobre decisões de investimentos.

15. Nos últimos doze meses, qual destas afirmativas descreve sua atitude de poupança/investimento?

Marcar apenas uma oval.

Eu não consigo economizar nada.

Em alguns meses eu consegui economizar um pouco e investir.

Consegui economizar em todos os meses e investir. 
07/06/2019

Pesquisa em finanças pessoais

16. Qual das seguintes afirmativas melhor descreve sua posição atual de investimento? Marcar apenas uma oval.

Eu tenho muitos investimentos diversificados e estou preparado para o futuro

Eu tenho uma quantidade certa de investimentos e me sinto tranquilo para enfrentar eventualidades

Tenho muito pouco (ou nenhum) investimento agora. Eu gostaria de poder investir mais.

17. Pra você, qual seria a melhor opção para investir ?

Marcar apenas uma oval.

Poupança
Previdência privada
Bens materiais
Títulos públicos
Títulos privado
Fundos de investimentos

18. Na sua opinião, o que mais causa incerteza na hora de realizar um investimento ? Marcar apenas uma oval

Não possuir conhecimento suficiente.

É necessário um montante alto para investir

Medo de perder dinheiro.

19. Ainda que você não seja um investidor, que frase define melhor sua opinião quanto ao assunto?

Marcar apenas uma oval.

Segurança financeira

Maximização de patrimônio

Não vejo vantagem, pois o dinheiro fica muito tempo parado.

\section{Conhecimento financeiro}

20. Na sua opinião, qual o melhor meio de se informar sobre finanças? Marcar apenas uma oval.

Internet

Livros, jornais ou cursos

Amigos e familiares ou pessoas que possuem mais entendimento do assunto

Outro:

21. Nos últimos seis meses, você buscou se informar sobre finanças? Marcar apenas uma oval.

Não, não tenho interesse.

Não, mas tenho interesse.

Já entendo o suficiente.

Sim, pois tenho interesse no assunto. 
07/06/2019

Pesquisa em finanças pessoais

22. Ainda que você não costume realizar nenhum tipo de planejamento, na sua opinião, qual o principal motivo que favorece a elaboração de um planejamento financeiro ?

Marcar apenas uma oval.

Ter total controle de gastos.

Auxiliar nas estratégias traçadas para que se alcance os objetivos.

Não vejo um motivo favorável para isso.

Powered by

Google Forms 